\title{
Trade Protectionism as the Achilles Heel of International Cooperation and Countermeasures Focused on the EU - Japan FTA ${ }^{1}$
}

\author{
S. -C. Park
}

Sang-Chul Park - PhD, Professor, Graduate School of Knowledge Based Technology and Energy, Korea Polytechnic University; 2121, Jeongwang-Dong, Siheung-City, Gyeonggi-Do, 429-793, Korea; E-mail: scpark@kpu.ac.kr

\begin{abstract}
Intensified trade protectionism led by the Trump administration in the U.S. negated the Trans-Pacific Partnership (TPP) Agreement until Japanese Prime Minister Abe restored it in 2018 without U.S. participation. At present, the trade wars between China and the U.S. and between the European Union (EU) and the U.S. are still ongoing processes and no one can predict exactly what the results will be for the global economy. Eventually, trade protectionism may be regarded as the Achilles heel of global economic cooperation. Despite the protectionist atmosphere, there is a pro free trade movement in the global economy. The EU and Japan started negotiations for a free trade agreement (FTA) in 2012 and finalized their agreement in December 2017 after 18 rounds of negotiation. The two parties agreed in principle on the main elements of the EU - Japan FTA. After a legal verification and translation process, the European Commission submitted the agreement for the approval of the European Parliament and EU members. As a highly developed economy and a major global trader and investor, Japan is one of the most important partners for the $E U$. The EU - Japan FTA will lead to extensive economic cooperation accounting for approximately $30 \%$ of global gross domestic product (GDP) in 2017. Moreover, the EU - Japan FTA removes many barriers and establishes global trade rules in line with the high standards of free trade and shared values. In addition, it sends a powerful signal that two major economies reject the protectionism that has arisen since the global financial crisis in 2008 in general and the Trump administration in 2017 in particular. This article focuses on the EU - Japan FTA and examines whether it will boost economic growth and provide benefits for both parties. It also investigates and analyzes which industrial sectors will profit the most in the two economies. Finally, it estimates the impact of the EU-Japan FTA on the global trade environment.
\end{abstract}

Key words: trade protectionism; trade barriers; global trade rules; free trade agreement (FTA); economic growth

For citation: Park S.-C. (2019) Trade Protectionism as the Achilles Heel of International Cooperation and Countermeasures Focused on the EU - Japan FTA. International Organisations Research Journal, vol. 14, no 2, pp. 163-191 (in Russian and English). DOI: 10.17323/1996-7845-2019-02-08.

\section{Introduction}

The global financial crisis in 2008 escalated existing anti-globalization sentiments and encouraged views in opposition to the neo-liberal commitment to free trade. In this context, many countries have attempted to curtail imports and impose restrictions on trade. As a result, at Group of 20 (G20) summits and meetings of finance ministers and central bank governors,

${ }^{1}$ The editorial board received the article in October 2018. 
agreements have been made to fight against all forms of protectionism in order to maintain open trade. Despite such clear statements by the major countries, the World Trade Organization (WTO) rejected the G20 position and addressed its official views on the new trend of increased trade protectionism as a result of the deepening global economic crisis [WTO, 2018].

Despite the recent trend toward protectionism, global trade has contributed to rapid economic growth since the second-half of 20th century. However, the growth in global trade has slowed, particularly since the global financial crisis in 2008 and the sovereign debt crisis faced by the European Union (EU) in 2010-11. Moreover, the Trump administration has started to apply high tariffs on trade with Canada, China, the EU, Russia, Korea, Turkey and others that will negatively affect the global economy. The impacts of trade conflicts could last longer than expected given that the impacts of rising protectionism between 1929 and 1932 lasted until the 1960s. Trade conflicts will cost $\$ 800$ billion, which is about $4 \%$ of global trade and $0.4 \%$ of global gross domestic product (GDP) in 2018 [Edwards, 2018; Martin, 2018] (see Fig. 1).

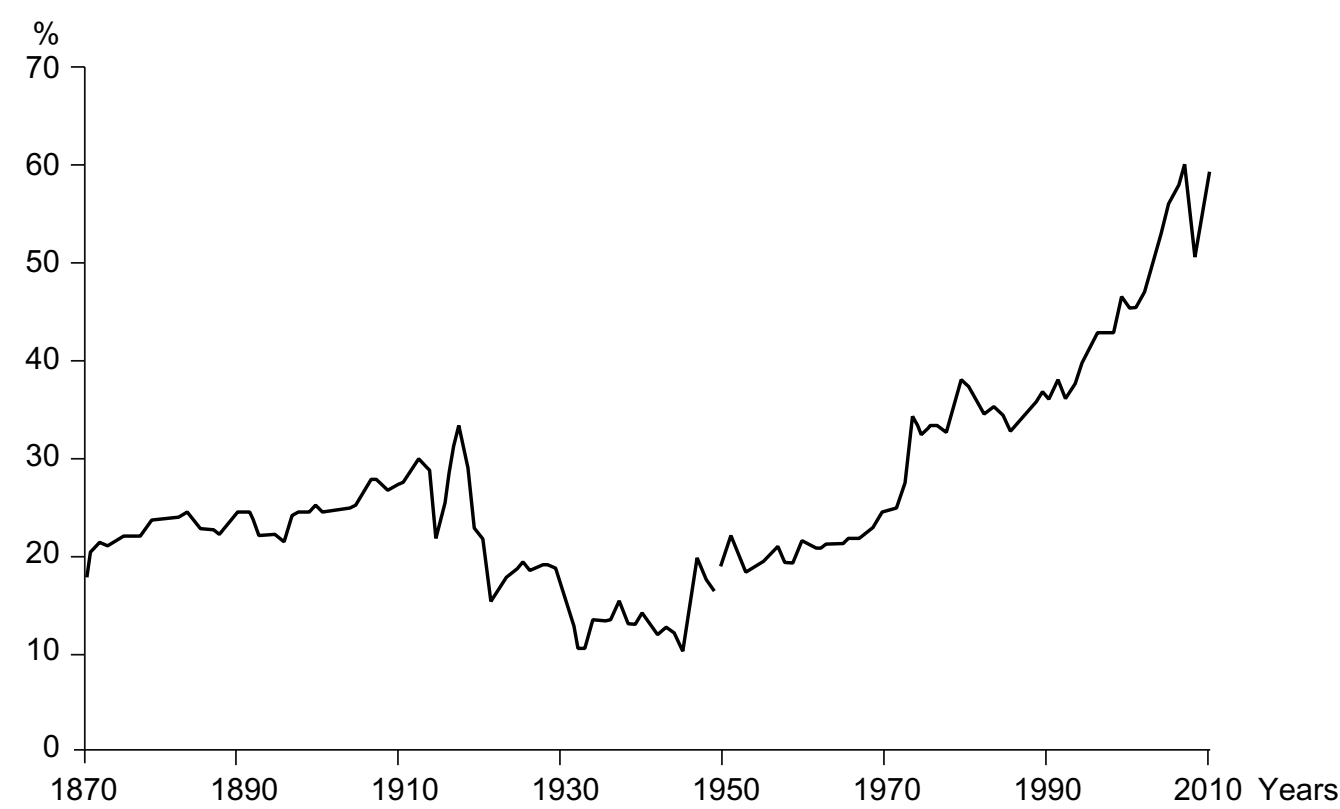

Fig. 1. World Trade to World GDP Ratio, 1870-2010

Source: [Ortiz-Ospina et al., 2018].

In this environment of protectionism and trade conflicts, the EU and Japan began negotiations for a free trade agreement (FTA) in 2012 and finalized it in December 2017 after 18 rounds of negotiation. The two parties each had reasons for moving their economic cooperation forward. The EU, suffering from two major economic crises, needed to strengthen its economy through external trade. Japan also needed to redevelop its economy after a long recession. In particular, the Abe administration was trying to reset the Japanese economy by participating in mega FTAs such as the Regional Comprehensive Economic Partnership (RCEP), the TransPacific Partnership (TPP) and the EU - Japan FTA.

Therefore, the two parties agreed in principle on the main elements of the EU - Japan FTA. After a legal verification and translation process, the European Commission (EC) sub- 
mitted the agreement for the approval of the European Parliament (EP) and EU members. The EU - Japan FTA entered into force 1February 2019. As a highly developed economy and a major global trader and investor, Japan is one of the most important partners for the EU, and vice versa. The trade relationships between the EU and Japan have traditionally been characterized by large trade surpluses in favour of Japan. However, the trade figures have become much more balanced in recent years because the EU has created trade surpluses in services with Japan while still having trade deficits in goods.

The EU - Japan FTA will lead to extensive economic cooperation accounting for approximately $30 \%$ of the global GDP in 2017. Moreover, the agreement removes many barriers and supports global trade rules in line with the high standards of free trade and shared values. It sends a powerful signal that two major economies reject the protectionism that has arisen since the global financial crisis in 2008 in general and the Trump administration in 2017 in particular, although the trade conflict between the Group of 2 (G2, China and the U.S.) is ongoing. Accordingly, the EU - Japan FTA may positively impact the global trade environment and could generate another model of a win-win approach to liberalized trade, along with the EU - Korea FTA established in 2011.

This article deals with how trade protectionism impacts global trade and the economy as a whole. Additionally, it focuses on the EU - Japan FTA as a countermeasure to trade protectionism, considering whether it is a win-win approach or win-lose approach. Finally, it investigates and analyzes the reasons each party completed the FTA and which industrial sectors profited the most in each country. Critical analysis of literature, inference and cross-sectional analysis based on statistical data are employed to address these issues.

\section{Theoretical Debates}

Most mainstream economists would agree with recent rebuttals to the scepticism about the liberal trading order. However, the intellectual and political support for free trade in the U.S. and elsewhere seems to be weakening, and the appeal of protectionism is increasing in many countries - particularly in the U.S. since the Trump administration in 2017.

Economic theory suggests that comparative advantages and economies of scale create economic gains through increased efficiency. Tariffs lead to competitive tariff retaliation, which results in a massive shrinkage of foreign trade and slow global economic growth. Economic theory never argued that free trade is good for all industries and all people. However, the winners from free trade can afford to compensate the losers and everyone can be made better off because the aggregate gains are positive [O'Rourke, Williamson, 2001; Rosen, 2008].

Economic theory also says that resources will flow to more efficient uses. However, this does not occur when governments and markets do not work well. P. Samuelson urged in 1972 that the aggregate gains from trade are not necessarily positive for all nations. He expanded his idea further to claim that growth in the rest of the world can damage a country if it takes place in sectors that compete with native exports at a comparative disadvantage. A nation's relative and even absolute GDP per capita can fall in such a condition. R. Gomory and W. Baumol extend Samuelson's theory and argue that there are many possible equilibria with vastly different outcomes for countries involved in a modern free trade world. They state further that it is perfectly possible and even common for a nation's equilibrium trade outcome to be less than an outcome of self-sufficiency. Thus, good equilibria are often created rather than bestowed by nature. Accordingly, countries can do much to affect their trading outcomes. Therefore, they urge U.S. protectionism in trade [Gomory, Baumol, 2009; Samuelson, 2004].

However, J. Bhagwati offers a criticism of this view, arguing that Samuelson's explanation cannot be used as a justification for U.S. protectionism. He also denies Gomory and Baumol's 
argument because the U.S. could not carry out effective industrial policies to remedy it although their argument is true. P.R. Krugman and M. Obsfeld share Bhagwati's criticism that whether the growth of emerging economies has hurt advanced countries is an empirical question rather than a fact, although the theoretical possibility exists [Bhagwati, 2009; Krugman, Obsfeld, 2009].

Economists have developed theoretical models for free trade to estimate welfare gains from reducing or eliminating trade barriers. In line with these models, P.R. Krugman, and C. Broda, and also D.E. Weinstein, suggest that trade benefits society through gains in overall quality and variety. However, this standard static growth from free trade has left trade promoters quite vulnerable because the static growth models only consider short-run partial equilibrium efficiency gains. At the same time, the static models suggest unimpressive gains from trade, ranging between 0.5-2\% of GDP [Broda, Weinstein, 2006; Krugman, 1979].

To deepen theoretical models in order to evaluate long-term efficiency gains and the contribution of free trade to economic growth, economists have developed dynamic models estimating the impacts of trade liberalization using cross-country regressions. Using these models, S. Bradford, P. Grieco and G.C. Hufbauer argue that the U.S. economy in 2005 would have been larger by $6.1-10.7 \%$ of GDP without post-war trade liberalization. However, S. Acemoglu leaves the issue of trade and growth undecided - because there are models that highlight both positive and negative effects of trade on economic growth, empirical work must be conducted. Accordingly, J.J. Lewer and H. van den Berg point out that further development of dynamic models and additional empirical research are required. Additionally, linkages between trade and technology, as well as trade and institutional quality, must be further developed [Acemoglu, 2009; Bradford, Grieco, Hufbauer, 2006; Feenstra et al., 2009; Lewer, van den Berg, 2007].

In this article, dynamic models rather than static models are adopted because the former can explain the long-term benefits of free trade more precisely than the latter. Accordingly, the conservative dualism of trade theory explains why U.S. protectionism has emerged since the global financial crisis and better represents the Trump administration's trade policy than any other theoretical background. However, it has limited ability to generate sustainable global economic growth. Therefore, it is possible that the dynamic models based on the long-term efficiency gains and economic growth can correct the move toward protectionism with a return to free trade. Furthermore, it also provides an explanation of why major and advanced economies such as the EU and Japan have advanced trade policies such as the EU - Japan FTA, focusing on free trade instead of protectionism.

\section{Trade Conflicts and Their Estimated Outcomes}

\section{Background}

The U.S. trade policy of the Trump administration is based on unilateralism and protectionism, focusing on U.S. economic interests first. It has resulted in conflicts with trading partners regardless of whether they are political allies or competitors. Each conflict involved the use of a U.S. legal rationale about threats to national security. The Trump administration has imposed tariffs and/or quotas on imports as a countermeasure to such threats. Subsequent retaliation by trading partners and the risk of further escalation could hamper trade and investment significantly, and in turn negatively affects the global economy. The U.S. trade conflict with its partners started when the U.S. International Trade Commission (USITC) recommended that President Trump impose global safeguard restrictions on imports of solar panels and washing machines. President Trump imposed safeguard tariffs on these items in January 2018 [Bown, Kolb, 2018].

Since then, trade conflicts with various partners have followed in which steel, aluminum and automobile products have been framed as national security threats, and in which trade 
practices for technology and intellectual property (IP) have been declared unfair. As a result, trade conflicts have spread on a global scale and deeply impacted the global economy continuously in 2018. The trade conflict between China and the U.S. is regarded as the most significant issue for the global economy due to their large economies and trade volumes.

\section{Trade Conflicts With Trading Partners}

There are four major issues at the core of U.S. trade conflicts: solar panel and washing machines, steel and aluminum, unfair trade practices for technology and intellectual property (IP), and automobiles and parts. The trade conflicts between the U.S. and its trading partners started when the USITC found that imports of solar panels and washing machines had caused injury to the U.S. solar panel and washing machine industries in October and November 2017, respectively. The two U.S. industries filed separate requests for investigations in early 2017 under Section 201 of the Trade Act of 1974; these were the first industry petitions since 2001. As a result, President Trump approved global safeguard tariffs on imports of solar cells and modules worth $\$ 8.5$ billion and on imports of large residential washing machines worth $\$ 1.8$ billion. These tariffs were approved in January 2018 and imposed on 7 February 2018. As a countermeasure, the Chinese government requested consultations with the U.S. within the WTO dispute settlement framework concerning these imports. China also requested that Korea join the consultations in February 2018. The Chinese government announced preliminary antidumping duties of $179.6 \%$ on imports of U.S. agricultural products, including sorghum, and imposed preliminary tariffs in April 2018. Chinese tariffs on U.S. sorghum ended by negotiation in May 2018. Furthermore, Korea filed WTO disputes against U.S. solar panel and washing machine tariffs in May 2018 on the grounds that they that violate WTO rules. China also filed a WTO dispute against U.S. solar panel tariffs in August 2018 [Bown, Kolb, 2018; Ng, Chung, 2018].

In April 2017, President Trump ordered two investigations into whether steel and aluminum imports threatened U.S. national security. These investigations were based on Section 232 of the Trade Expansion Act of 1962. The Department of Commerce found in February 2018 that imports of steel and aluminum products indeed threatened U.S. national security. Based on these findings, Trump announced that tariffs of $25 \%$ on steel and $10 \%$ on aluminum would be applied to all its trading partners, amounting to imports worth an estimated $\$ 48$ billion coming mostly from U.S. allies such as Canada, the EU, Mexico and Korea. The Chinese portion covered only $6 \%$ of imports due to the prior U.S. imposition of antidumping and countervailing duties. As a result, the Chinese retaliatory tariffs on this issue only accounted for $\$ 3$ billion. Due to a strong retaliatory response from the EU and other trading partners, Trump issued revised formal steel and aluminum tariff proclamations exempting the EU, Korea, Brazil, Argentina and Australia in March 2018, in addition to Canada and Mexico which were temporally exempted through May 2018. Tariffs on steel and aluminum went into effect in March 2018 with exemptions for these selected countries. A steel tariff of $25 \%$ applied to countries that had exported steel products worth $\$ 10.2$ billion to the U.S. in 2017, while the aluminum tariff of $10 \%$ applied to countries that had exported aluminum worth $\$ 7.7$ billion in the same year. The U.S. government renewed exemptions for selected countries but ended these over time. As tariff exemptions ended, Canada, the EU and Turkey imposed retaliatory tariffs on related or other U.S. products. China also imposed tariffs on various imports from the U.S. that included 128 tariff lines. Korea received a permanent exemption for steel, but agreed to reduce steel exports to the U.S. market; its agreed-to quota of 2.68 million tons reduced its shipment by $21.2 \%$ from the export volume in 2017 [Bown, Kolb, 2018; Jun, 2018; Ng, Chung, 2018].

In addition to steel and aluminum, the U.S. Trade Representative (USTR) initiated an investigation of China under Section 301 of the Trade Act of 1974 after President Trump's 
instruction in August 2017 to investigate any Chinese laws, policies or practices that may harm U.S. intellectual property rights, innovation or technological development. The USTR found that China conducted unfair trade practices related to technology transfer, intellectual property and innovation, and thus President Trump imposed 25\% tariffs on 1,333 Chinese products in two phases starting July 2018, accounting for $\$ 50$ billion worth of targeted intermediate inputs and capital products. China also issued an updated $\$ 50$ billion retaliation list of $25 \%$ tariffs including agricultural and food products, crude oil, automobiles, airplanes, chemical products, medical equipment and energy products in two phases that accounted for 659 tariff lines. Since then, trade conflicts between China and the U.S. have continued, and in June 2018 President Trump directed the USTR to identify Chinese imports worth an additional \$200 billion for an additional tariff of $10 \%$ in response to Chinese retaliatory tariffs. The USTR finalized a tariff list containing 5,745 full or partial lines of the original 6,031 tariff lines that were on a proposed list of Chinese imports. The additional tariff came into effect in September 2018 [Bown, Kolb, 2018; McLarty Associates, 2018; Ng, Chung, 2018; USTR, 2018].

In May 2018, the U.S. Commerce Department initiated a third national security investigation into imported autos and parts following the steel and aluminum cases. President Trump considered raising tariffs to $25 \%$ on these products, which are mainly imported from the EU, Japan and Korea. Tariffs on autos are not yet imposed. Overall, because trade conflicts are composed of four different issues and involve still ongoing processes, it is extremely difficult to estimate how they will develop in the future (see Table 1).

Table 1. Category and Content of U.S. Trade Conflicts with Trading Partners

\begin{tabular}{|l|l|}
\hline \multicolumn{1}{|c|}{ Category } & \multicolumn{1}{c|}{ Content } \\
\hline Solar panels and washing machines & $\begin{array}{l}\text { Imposition of safeguard tariffs on imports of solar panels worth \$8.5 } \\
\text { billion and of washing machines worth \$1.8 billion. } \\
\text { Chinese preliminary tariffs on U.S. sorghum and the filing of a WTO } \\
\text { dispute against U.S. solar panel tariffs. } \\
\text { Korean filing of a WTO dispute against U.S. solar panel and washing } \\
\text { machine tariffs }\end{array}$ \\
\hline Steel and aluminum as threats to national security & $\begin{array}{l}\text { Section 232 of Trade Expansion Act of 1962. } \\
25 \% \text { on steel and 10\% on aluminum covering imports worth \$48 } \\
\text { billion }\end{array}$ \\
\hline $\begin{array}{l}\text { Unfair trade practices for technology and } \\
\text { intellectual property (IP) }\end{array}$ & $\begin{array}{l}\text { Section 301 of Trade Act of 1974. } \\
1,333 \text { Chinese products worth \$50 billion for 25\% tariffs with two } \\
\text { phases. } \\
\text { Identifying imports worth \$200 billion for 10\% tariffs }\end{array}$ \\
\hline Autos as threats to national security & Raising tariffs up to 25\% \\
\hline
\end{tabular}

Source: [Bown, Kolb, 2018; McLarty Associates, 2018; Ng, Chung, 2018; USTR, 2018].

\section{Outcomes of Trade Conflicts}

Global trade tensions have substantially increased since the arrival of the Trump administration in 2017. The U.S. has imposed tariffs on various imports from its trading partners and its trading partners have responded with retaliatory measures. The outlook has been clouded by ongoing trade tensions after President Trump announced the imposition of $10 \%$ tariffs on Chinese imports worth $\$ 200$ billion starting on 24 September 2018, and the Chinese government's retaliatory imposition of 5-10\% tariffs on U.S. imports worth $\$ 60$ billion [Bown, Jung, Lu, 2018; Grace, 2018; IMF, 2018].

Most analyses of trade conflicts by economists conclude that tariffs imposed by the Trump administration and other trading partners do not damage macroeconomic development in the 
short run. Taken together, the tariff of $25 \%$ on U.S. imports worth $\$ 50$ billion and the tariff of $10 \%$ on imports worth $\$ 200$ billion increase import costs by $\$ 32.5$ billion. This is a very small amount compared with the total U.S. GDP of $\$ 19.6$ trillion a year. In fact, it accounts for only $0.17 \%$ of the U.S.' GDP in 2017. However, the tariff escalation by China and the U.S. could negatively impact global trade. Based on a computable general equilibrium (CGE) analysis by the World Bank Group, this escalation could reduce global exports by up to 3\%, or $\$ 674$ billion. In addition, the trade disputes in the G2 could reduce global income by up to $1.7 \%$ with losses across all regions amounting to $\$ 1.4$ trillion [Freund et al., 2018; Lawrence, 2018].

The U.S. - China trade conflict impacts developing nations both positively and negatively. Third-party countries could benefit from increased preference margins in the U.S. and Chinese markets when the two nations impose tariffs on their imports. However, when investor confidence becomes unstable, these gains disappear in all regions due to negative income effects. As a result, income losses range from $0.9 \%$ in South Asia to $1.7 \%$ in Europe and Central Asia. Furthermore, the biggest declines of income are recorded by China and the U.S. with $3.5 \%$ and $1.6 \%$ respectively. Agricultural, chemical and transport equipment products are affected mostly in the U.S., while electronic equipment, machinery and manufacturing products lose mostly in China [Freund et al., 2018].

According to an analysis by the International Monetary Fund (IMF), an escalation of trade tensions could weaken business and financial market sentiment leading to declines in investment and trade. Moreover, proliferation of tariffs and retaliatory measures increases uncertainty about the potential breadth of trade, which hinders investment. As a result, higher trade barriers make goods and services less affordable. The IMF has warned that the threats to impose tariffs by the U.S. and its trading partners could reduce global economic growth by $0.5 \%$ by 2020 - that is equivalent to a loss of about $\$ 430$ billion from the global GDP [IMF, 2018; Partington, 2018].

An analysis by A. Slater in Oxford Economics has produced an even more negative estimation than the above-mentioned analyses. It estimated that the auto tariffs threatened by President Trump to U.S. allies in Europe, China and other trading partners could reduce world trade by $4 \%$ and wipe away $\$ 800$ billion from the global GDP if they are imposed in 2019 . This would have a significant negative impact on the global economy because oil prices and interest rates are both rising globally [Edwards, 2018] (see Fig. 2, Table 2).

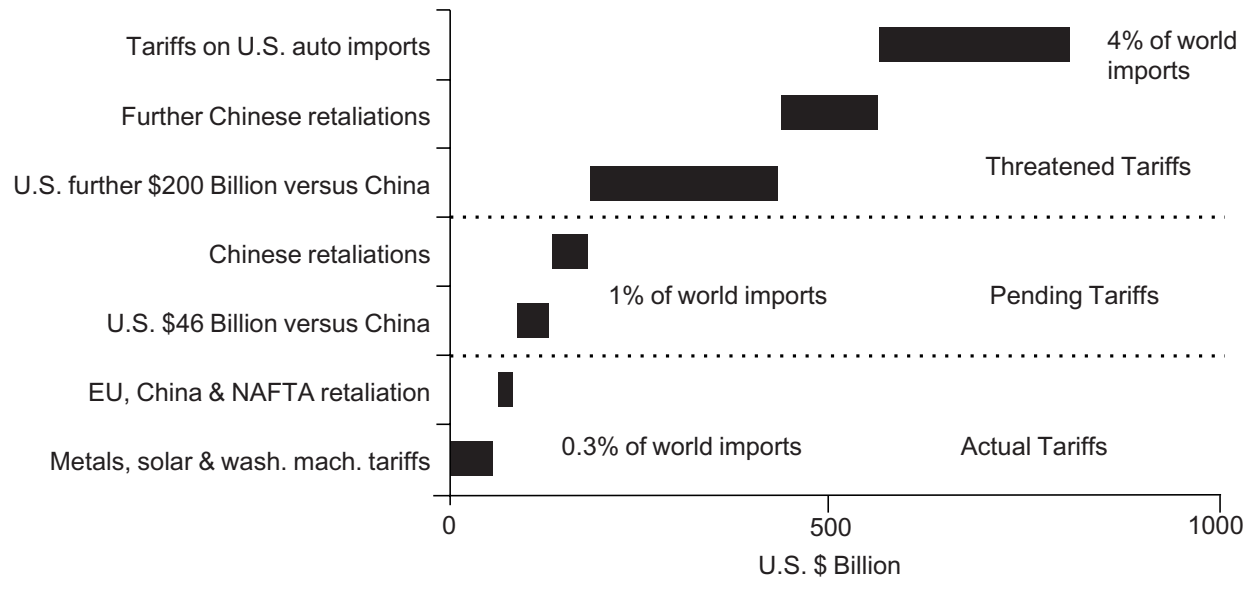

Fig. 2. Trade Conflicts and Their Costs

Source: [Edwards, 2018]. 
Table 2. Estimated Outcomes of Trade Conflicts

\begin{tabular}{|l|c|}
\hline \multicolumn{1}{|c|}{ Analysis } & Estimated Cost (\$ Billion) \\
\hline World Bank Group & 674 \\
\hline IMF & 430 \\
\hline Oxford Economics & About 800 \\
\hline
\end{tabular}

Source: Author's own adaptation based on [Edwards, 2018; Freund et al., 2018; IMF, 2018].

Beyond the decline in trade and slowed global economic growth, the trade conflicts could damage global supply and value chains as well as inhibit the spread of new technologies that increase productivity. The long-term impact on the global value chains will be to destroy the confidence of companies that operate in these chains. They cannot continue to cope with unstable conditions for global market access. Even in the short run, they must delay their investment plans due to increased uncertainty [Freund et al., 2018; IMF, 2018; Lawrence, 2018].

\section{EU and Japan's Trade Policy Strategy}

\section{Background}

The EU Commission has adapted its trade strategy every few years based on pragmatic approaches since the late 1990s. The EU originally advanced a policy of managed globalization that aimed to adapt the global rules and strengthen international regimes in order to mitigate anti-globalization protests. In line with this strategy, the EU strongly advocated for a multilateral trade round in the WTO. The EU adhered to the Lisbon strategy (2000) which aimed to make the EU the most competitive and dynamic knowledge-based economy in the world by 2010 . As part of a less ambitious Lisbon strategy, "renewed" following its midterm review in 2005, the EU realized that trade contributed to economic growth and new job creation. In 2006, the EU adopted a Global Europe trade strategy, preferring FTA partners based on market potential, their level of protection against EU exports, and their negotiations with EU competitors. Since 2015, the EU has implemented a trade strategy called Trade for All which aims to deliver economic growth and new jobs without compromising core principles [Gstöhl, 2016].

Compared to the EU's strategy, since World War II Japanese economic and trade policy has mainly focused on a multilateral, rather than bilateral or regional, approach although Japan did support East Asian regionalism because Japanese companies had a significant advantage over their rivals. Until the end of 1990s, Japan preferred the participation of the U.S. in any economic grouping of trade partners such as the Asia-Pacific Economic Cooperation (APEC), the TPP and others, despite its strong economic expansion [Park, Pasierbiak, 2018].

However, Japanese trade policy started to change as the Chinese emerged in the East Asian region after 2000. China was particularly active in terms of trading with East Asian countries. When China started to negotiate an FTA with ASEAN, Japanese trade policy also changed in favour of FTAs in the East Asian region. As a result, Japan focused on trade and foreign direct investment (FDI) for its production bases resulting in a significant increase of FTAs within the region in the period 2002-16. Since then, Japanese trade policy has been to implement bilateral, multilateral and mega FTAs [Baldwin, 2007; 2011; Park, 2017]. 


\section{EU and Japanese Trade Policy}

The EU's trade policy for Global Europe focused on bilateral FTAs and bloc-to-bloc agreements, particularly with the Association of Southeast Asian Nations (ASEAN), the South American Trade Bloc (Mercosur) and the Gulf Cooperation Council. In bilateral FTAs, the EU envisaged possible important partners such as India, Japan, Russia and Korea. Additionally, the EU communicated with China to explore a bilateral FTA. In fact, the EU regarded China as the single greatest test of Europe's capacity to generate economic growth and employment through the globalization of trade policy. As a result, a far-reaching FTA with Korea was signed in 2010 and ratified by the EP. The EU - Korea FTA was the first FTA with an Asian country and the first of the new generation of FTAs. It became the benchmark agreement [de Prado, 2014].

The global financial crisis and the sovereign debt crisis impacted the Europe 2020 strategy which followed on the renewed Lisbon strategy. The Europe 2020 strategy aimed at smart, sustainable and inclusive growth. In this context, the strategy for Trade, Growth and World Affairs (TGWA) was regarded as an update to the Global Europe strategy followed since 2010. It emphasized reciprocity; particularly in relation to emerging economies, the EU's trade and foreign policies must be mutually reinforcing and must encourage its partners to promote respect of human rights, labour and environmental standards, sustainable development and investment.

The target partners for the TGWA strategy were chosen by large economies such as the U.S., Japan and Canada, and individual ASEAN states were included because the bloc-to-bloc approach had failed. In the early 2010s, the global trade environment confronted protectionism, and the global economic condition was sluggish until 2016. Therefore, major economies tried to set up mega FTAs such as the Regional Comprehensive Economic Partnership (RCEP) and the TPP. The EU was no exception. It started talks on a bilateral investment agreement (BIA) with China, while the U.S. engaged with the TPP. In order to strengthen cross-Atlantic economic cooperation, the EU opened negotiations for the Transatlantic Trade and Investment Agreement (TTIP) in 2013; these have remained stalled since President Trump took office in 2017. These are all strategic responses to the changing global trade order [Gstöhl, 2016].

During increasing controversy over the TTIP due to the investor-to-state dispute settlement (ISDS) mechanism, and half-way through the Europe 2020 strategy, the EU presented a new trade strategy called Trade for All in 2015. In the new strategy, the EU demanded more transparency, attention to regulatory issues and dispute settlement in investment and expressed concerns about the external effects of FTAs. As a result, it generated higher transparency as standard practice in the negotiations for the TTIP and effectively extended measures to trade defense. The EU's strategic focus is to ensure trade agreements delivering concrete benefits to its economy and people though economic growth and employment in the EU [EC, 2017] (see Table 3).

Table 3. EU's Trade Policy Strategies, 1990s-2015

\begin{tabular}{|l|l|l|}
\hline \multicolumn{1}{|c|}{ Period } & \multicolumn{1}{c|}{ Trade Policy } & \multicolumn{1}{c|}{ Strategy } \\
\hline 1990s & Multilateral trade round & Adopt global rules and international regimes \\
\hline $2000-2015$ & Bilateral FTAs for Global Europe & Lisbon strategy and renewed Lisbon strategy \\
\hline Since 2015 & $\begin{array}{l}\text { Trade and foreign policy mutually } \\
\text { reinforced based on reciprocity: } \\
\text { Trade for All }\end{array}$ & Europe 2020 strategy and TGWA strategy \\
\hline
\end{tabular}

Source: compiled by the author. 
In order to make free trade fair, the EU has used all possible tools to enforce commitments undertaken by FTA concluded partners. It has claimed to remove trade barriers and to prohibit unfairness to safeguard a level playing field for EU companies. Moreover, the EU enforced its rights though the WTO dispute settlement mechanism whenever it was necessary. As a result, the EU pursued 21 complaints in the WTO with 10 trade partners in 2017 and became the second-biggest user of the system along with the United States. Additionally, trade defense instruments (TDI) have ensured that EU companies face fair competition in open trade. Moreover, the EU works closely with stakeholders such as the EC, the EP and member states to maximize opportunities created by FTAs. In fact, around $40 \%$ of the EU's total exports are covered by implemented or concluded FTAs. Therefore, it is vital for the EU to manage its FTAs properly in order to generate economic growth and new employment [EC, 2017].

Even after the creation of the WTO in 1995, Japanese trade policy did not adapt to the reality that regional and bilateral trade agreements had overwhelmed the multilateral trading system based on the rules of the WTO. Therefore, Japan rejected any bilateral and regional free trade agreements in favour of non-discriminatory economic cooperation. Japanese trade policy was against free trade agreements until 1998 because these could create adverse effects for nonmember states. Moreover, these effects could be controlled through international organizations such as APEC or the WTO. In fact, the anti-FTA trade stance supported Japanese agricultural policy's resistance to liberalization beyond GATT negotiations. Additionally, it also contributed to protecting Japanese companies investing abroad assisted by official development assistance (ODA). Japanese trade policy, for 50 years in the post-war period, focused on accessing global markets based on multilateralism. Global market access was a precondition for Japan to acquire low-cost capital goods, high technologies, raw materials and food supplies that could provide industrial success and economic prosperity [Dyrsdale, Armstrong, 2014; Yamamoto, Kikuchi, 1998].

However, after the Asian financial crisis (AFC) in 1997, Japanese trade policy turned from multilateralism to bilateralism in order to secure its regional trade interests, resulting in a high degree of trade and investment integration in the East Asian economy. After the AFC, Japanese trade policy aimed to revive trade growth through an FTA strategy. This was a significant shift in Japanese trade policy. As a result, the multilateral trading system began to end in favour of preferential trade agreements in 1998, due not to debates in policymaking circles, but rather to Japan and East Asia's quest for stronger institutional ties. Japan launched joint studies on FTAs with Korea in 1998 and Singapore in 2000 [Dyrsdale, Armstrong, 2014].

Japan and Singapore completed an FTA in 2002. However, its significance was mostly symbolic due to the failure to liberalize tariffs and the agricultural sector in order to protect Japanese agriculture even in a bilateral FTA. Additionally, Japan offered all developing nations negotiating FTAs investment and economic cooperation while keeping its own agricultural sector largely protected. Similar measures were offered to developed economies, that is, service sectors were to be excluded from FTA negotiations in order to protect them. Such strategies cannot contribute to trade growth because they are not sufficiently comprehensive and have no real economic impact on either party [Mitsuyo, Fukunari, 2008].

In fact, Japan signaled strong support for the multilateral system and the most favourable nation (MFN) principle which resulted in a proliferation of FTAs among Japan's neighbours, including Korea, China and the ASEAN states. Despite this, Japan launched economic partnership agreement (EPA) negotiations with Korea, Mongolia, Canada, the EU and others. However, the impacts of the agreements have been limited because Japanese EPAs seek to protect Japan's agriculture and service sectors, thus limiting the interests in the agreements by partners. As a result, Japan could not produce strategic national reform to meet its economic growth goal. Japan's early FTAs were politically, diplomatically and strategically oriented rather 
than focused on deliberation of economic costs and benefits [Dyrsdale, Armstrong, 2014; Tatsushi, 2002].

During the 2000s, investment by the Japanese government in infrastructure in Southeast Asia and South Asia began, and contributed to building supply chains and economic development in the region. The primary motivation for the investment was to support Japan's multinational companies (MNCs) in exporting equipment, machinery and engineering services in the region. However, this trade policy was not connected with domestic reforms and failed to bring South Asia into an integrated East Asian economic system.

In this context, the U.S. and China started to build mega FTAs such as the RCEP and the TPP. ${ }^{2}$ Beginning in the 2010s, Japan actively participated in these mega FTAs in order to build a new global trade and economic governance structure in the Asia Pacific region. However, at the same time, Japan continues to avoid agricultural and service reform while participating in RCEP and TPP. Much action can take place domestically, beyond the TPP and the RCEP [Dyrsdale, Armstrong, 2014] (see Table 4).

Table 4. Japanese Trade Policy Strategies, 1945-2018

\begin{tabular}{|l|l|l|}
\hline \multicolumn{1}{|c|}{ Period } & \multicolumn{1}{|c|}{ Trade Policy } & \multicolumn{1}{c|}{ Strategy } \\
\hline Pre-1998 & $\begin{array}{l}\text { Multilateral trade round to access global } \\
\text { market }\end{array}$ & $\begin{array}{l}\text { Adopt global rules and international regimes } \\
\text { (GATT/WTO) }\end{array}$ \\
\hline 1999-2000s & Bilateral FTA/EPA for global market & $\begin{array}{l}\text { Protect agricultural sector from developing } \\
\text { countries and service sector from developed } \\
\text { countries }\end{array}$ \\
\hline Post-2010s & Bilateral and mega FTAs & $\begin{array}{l}\text { Economic growth through trade } \\
\text { (Abenomics) }\end{array}$ \\
\hline
\end{tabular}

Source: compiled by the author.

\section{Trade and Foreign Direct Investment (FDI) between the EU and Japan}

Bilateral trade between the EU and Japan has been strengthened since the 1990s. The EU increased economic and political relations with Japan after a series of European treaty reforms. As a result, the two economies are already closely interlinked, although the $28 \mathrm{EU}$ member states do not have the same degree of trade relations with Japan. The Japanese share of total exports to the EU accounted for over 5\% in 2000, while the EU's share of total exports to Japan was around $17 \%$ in the same year. These shares declined to $3 \%$ and nearly $10 \%$ respectively in 2013. Since then, there has been an upward trend to over $3 \%$ and $11 \%$ respectively in 2016, but these shares are still much lower than in 2000. The decline in shares of exports from 2000 to 2013 in both markets can be explained by the rapid expansion of Chinese exports to the EU and Japan [EPSC, 2017] (see Fig. 3).

The EU was Japan's third-largest trade partner after China and the U.S. in 2017, while Japan was the sixth-largest trade partner of the EU in the same year. In Asia, Japan was the second-largest trade partner of the EU after China, ahead of Korea and India. Japan was the seventh-largest trade partner of the EU in imports with its share accounting for 3.7\%, while it was the sixth-largest trade partner of the EU in exports with a share of $3.2 \%$ in 2017. The EU's

${ }^{2}$ The TPP became the Comprehensive and Progressive Trans-Pacific Partnership (CPTPP) in March 2018 following Japan's strong push, along with other remaining members such as Australia, Canada, Mexico, New Zealand and Singapore, to revive the agreement after the U.S. announced its official with drawal from the TPP in January 2017. 
total trade with Japan was still far behind its trade total with China. However, the quality of traded goods must be mutually beneficial for the EU and Japan as a whole [de Prado, 2014; EC, n. d.; EPSC, 2017] (see Table 5).

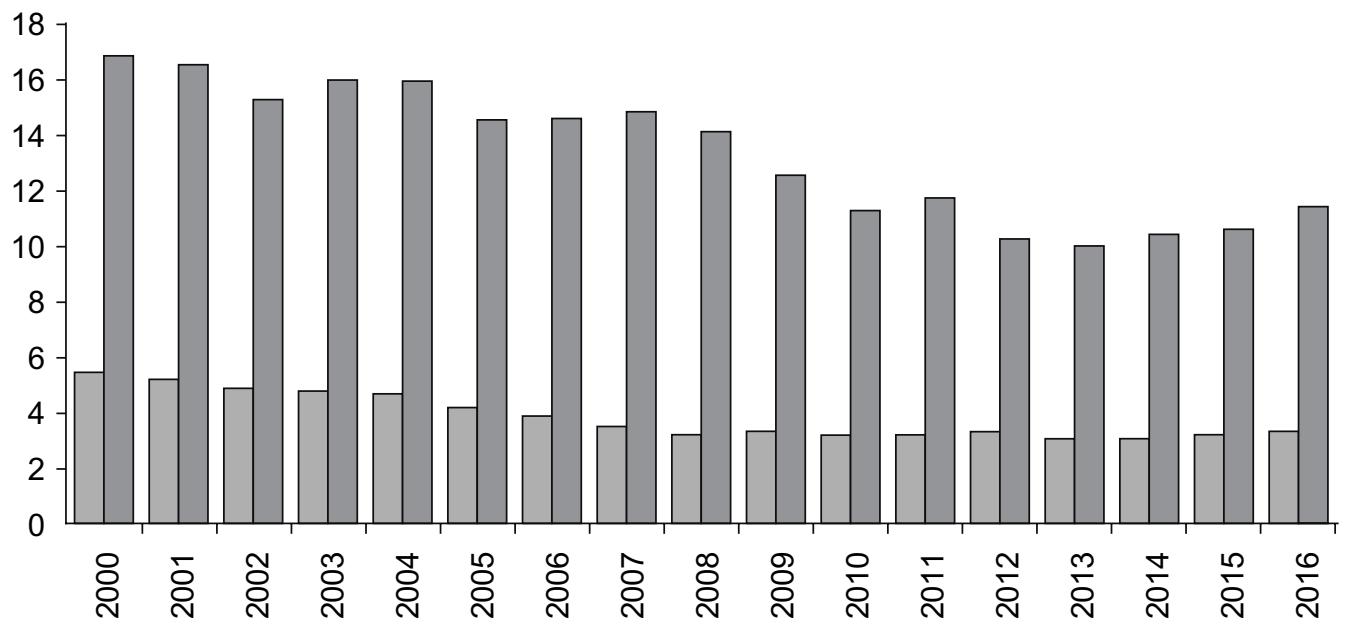

Share of Japan in EU's export

Share of EU in Japan's export

Fig. 3. Share of Respective Total Exports to the EU and Japan as of 2000-16 (\%)

Source: [Eurostat, 2017; IMF, 2017].

Table 5. EU's Top 10 Trade Partners as of 2017

\begin{tabular}{|l|l|c|c|l|l|c|l|c|c|}
\hline \multirow{2}{*}{} & \multicolumn{3}{|c|}{ Imports } & \multicolumn{3}{c|}{ Export } & \multicolumn{3}{c|}{ Total trade } \\
\cline { 2 - 10 } & Partner & $\begin{array}{c}\text { Value } \\
\text { Mio € }\end{array}$ & $\begin{array}{c}\text { Extra- } \\
\text { EU, } \\
\%\end{array}$ & Partner & Value Mio € & $\begin{array}{c}\text { Extra- } \\
\text { EU, } \\
\%\end{array}$ & $\begin{array}{l}\text { Partner } \\
\text { Value } \\
\text { Mio € }\end{array}$ & $\begin{array}{c}\text { Extra- } \\
\text { EU, } \\
\%\end{array}$ \\
\hline 1 & World & 1.858 .257 & 100.0 & World & 1.879 .431 & 100.0 & World & 3.737 .688 & 100.0 \\
\hline 2 & U.S. & 256.176 & 13.8 & China & 198.200 & 10.5 & China & 573.023 & 15.3 \\
\hline 3 & Russia & 145.094 & 7.8 & Switzerland & 150.813 & 8.0 & Switzerland & 261.220 & 7.0 \\
\hline 4 & Switzerland & 110.407 & 5.9 & Russia & 86.186 & 4.6 & Russia & 231.280 & 6.2 \\
\hline 5 & Norway & 77.433 & 4.2 & Turkey & 84.490 & 4.5 & Turkey & 154.251 & 4.1 \\
\hline 6 & Turkey & 69.760 & 3.8 & Japan & 60.493 & 3.2 & Japan & 129.373 & 3.5 \\
\hline 7 & Japan & 68.880 & 3.7 & Norway & 50.702 & 2.7 & Norway & 128.135 & 3.4 \\
\hline 8 & Korea & 50.017 & 2.7 & Korea & 49.805 & 2.7 & Korea & 99.822 & 2.7 \\
\hline 9 & India & 44.184 & 2.4 & OAЭ & 42.616 & 2.3 & India & 85.907 & 2.3 \\
\hline 10 & Vietnam & 37.018 & 2.0 & India & 41.723 & 2.2 & Canada & 69.182 & 1.9 \\
\hline
\end{tabular}

Source: [Eurostat, 2018].

There has been a chronic deficit in the EU's balance of trade in goods with Japan for a long time. However, this deficit declined continuously until 2013 and started to increase after 2014. The EU's trade with Japan in goods and services increased from $€ 116.3$ billion in 2015 
to $€ 129.4$ billion in 2017 and from $€ 40.1$ billion in 2014 to $€ 49$ billion in 2016 respectively. The EU had a trade deficit in goods and a trade surplus in services. In Japan, it was the opposite. On the whole, the EU has a trade surplus with Japan owing to the comparative competitiveness in services. In recent years, even though the EU's trade deficit in goods with Japan increased, its trade surplus in services grew faster than its trade deficit [EC, n. d.] (see Table 5, Fig. 4, 5).

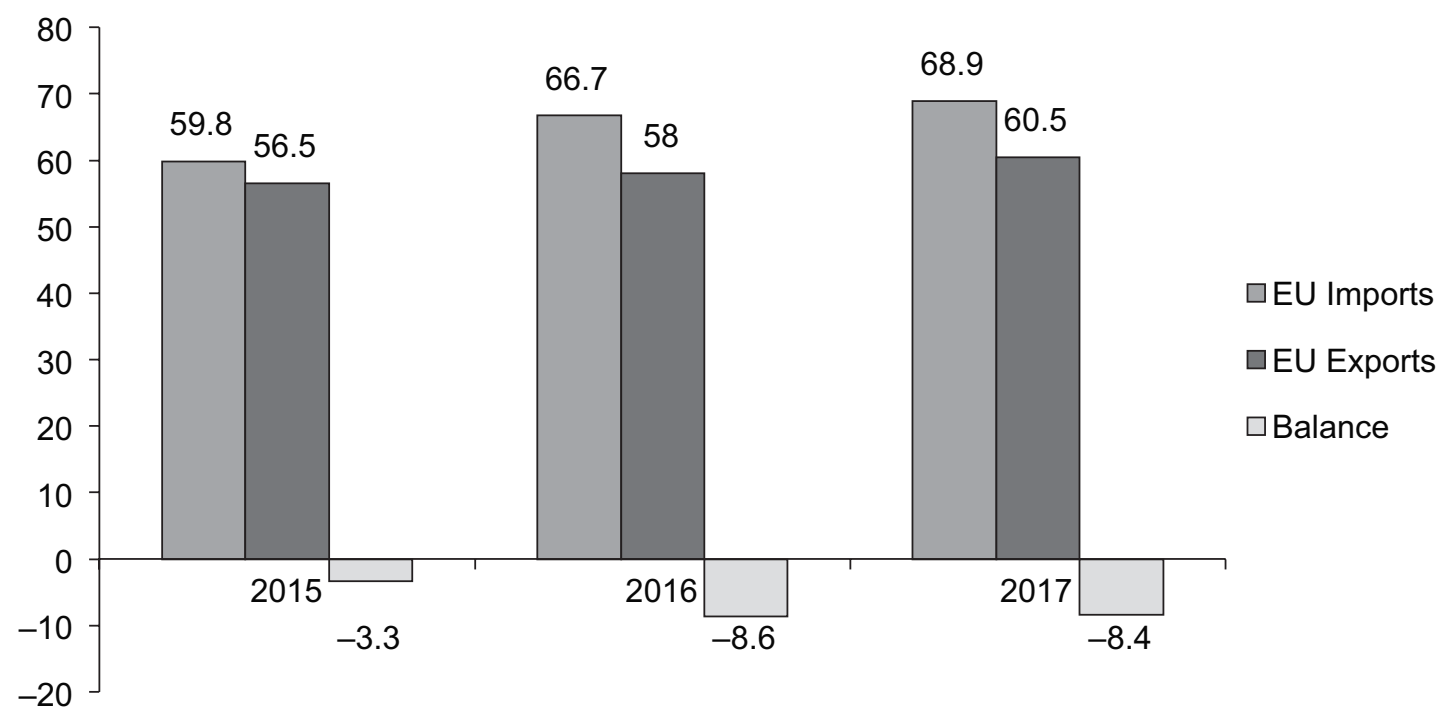

Fig. 4. EU's Trade in Goods With Japan, 2015-17 (€ Billion)

Source: [EC, n. d.; 2018a].

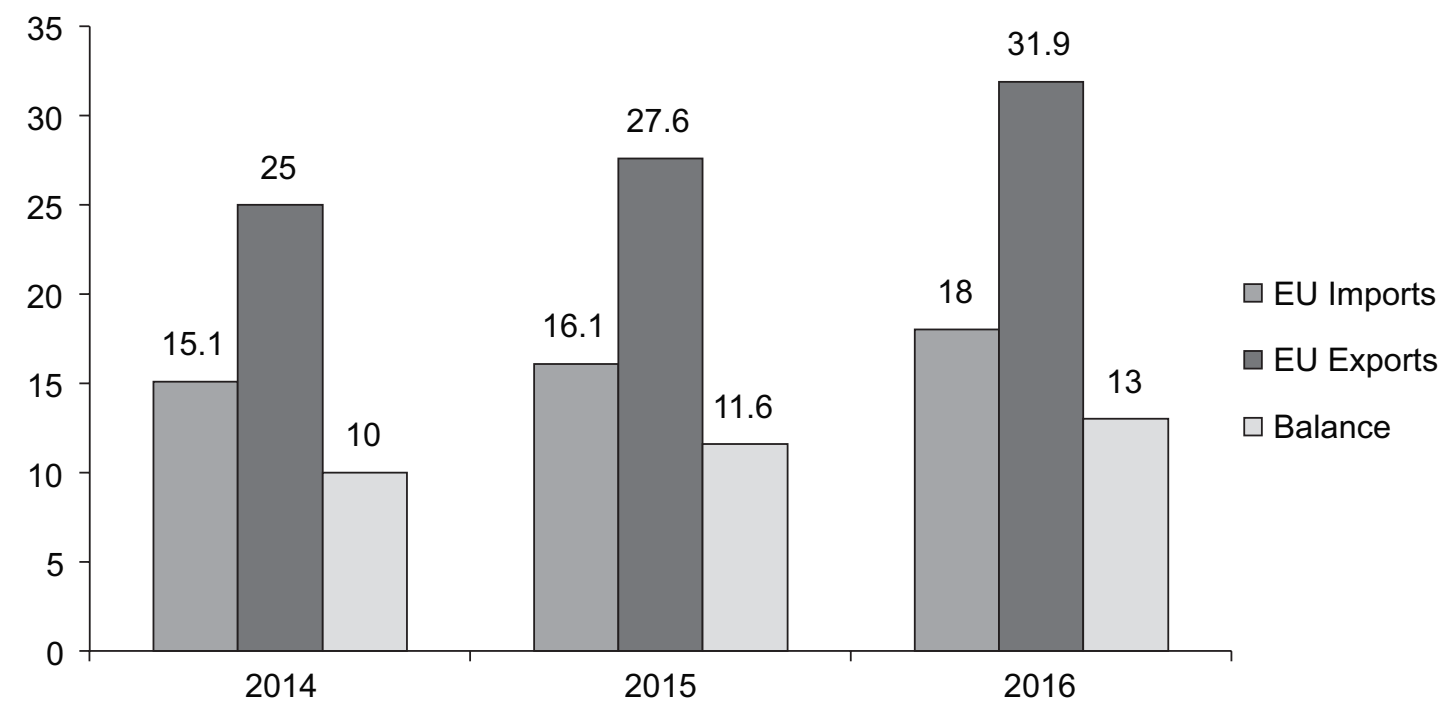

Fig. 5. EU's Trade in Services with Japan, 2015-17 (€ Billion)

Source: [EC, n. d.; 2018a]. 
Japan imported goods from the EU worth over $€ 69.1$ billion in 2017 and exported goods to the EU worth over $€ 68.4$ billion in the same year. The EU was the second-largest import origin and the third-largest export destination for Japan. In total, the EU was the third-largest partner of Japan with trade worth over $€ 137.5$ billion, after China and the U.S. but ahead of Korea. The share of Japanese trade with the EU accounted for 11.3\% of its total trade share [EC, 2018a] (see Table 6).

Table 6. Japan's Top 10 Trading Partners, 2017

\begin{tabular}{|l|l|c|c|l|c|c|l|c|c|}
\hline \multirow{2}{*}{} & \multicolumn{3}{|c|}{ Imports } & \multicolumn{3}{c|}{ Export } & \multicolumn{3}{c|}{ Total trade } \\
\cline { 2 - 10 } & Partner & Value Mio $€$ & $\begin{array}{c}\text { World, } \\
\%\end{array}$ & Partner & Value Mio $€$ & $\begin{array}{c}\text { World, } \\
\%\end{array}$ & Partner & $\begin{array}{c}\text { Value Mio } € \\
\text { World, } \\
\%\end{array}$ \\
\hline 1 & World & 594.125 & 100.0 & World & 617.928 & 100.0 & World & 1.212 .053 & 100.0 \\
\hline 2 & EU 28 & 69.120 & 11.6 & China & 117.568 & 19.0 & U.S. & 184.926 & 15.3 \\
\hline 3 & U.S. & 65.359 & 11.0 & EU 28 & 68.412 & 11.1 & EU 28 & 137.532 & 11.3 \\
\hline 4 & Australia & 34.509 & 5.8 & Korea & 47.191 & 7.6 & Korea & 72.078 & 5.9 \\
\hline 5 & Korea & 24.887 & 4.2 & Taiwan & 35.979 & 5.8 & Taiwan & 58.450 & 4.8 \\
\hline 6 & $\begin{array}{l}\text { Saudi } \\
\text { Arabia }\end{array}$ & 24.558 & 4.1 & $\begin{array}{l}\text { Hong } \\
\text { Kong }\end{array}$ & 31.375 & 5.1 & Australia & 48.685 & 4.0 \\
\hline 7 & Taiwan & 22.471 & 3.8 & Thailand & 26.058 & 4.2 & Thailand & 46.171 & 3.8 \\
\hline 8 & Thailand & 20.114 & 3.4 & Singapore & 20.049 & 3.2 & Hong Kong & 32.992 & 2.7 \\
\hline 9 & $\begin{array}{l}\text { United } \\
\text { Arab } \\
\text { Emirates }\end{array}$ & 18.351 & 3.1 & Australia & 14.176 & 2.3 & Vietnam & 29.709 & 2.5 \\
\hline 10 & Indonesia & 17.529 & 3.0 & Vietnam & 13.228 & 2.2 & Indonesia & 29.386 & 2.4 \\
\hline
\end{tabular}

Source: [IMF, 2018].

The top five major goods exported by Japan to the EU in 2016 were machinery and appliances, transport equipment, products of the chemical or allied industries, optical and photographic instruments, and plastics, rubber and articles. These items accounted for $87 \%$ of total exports. Japan imported from the EU mainly products of the chemical or allied industries, machinery and appliances, transport equipment, optical and photographic instruments, and foodstuffs, beverages and tobacco in the same year. These top five import items accounted for 74.4\% of total imports [Deloitte, 2018; Government of Japan, 2017a, 2017b] (see Table 7, 8).

The largest share of Japanese imports from the EU was in medical products, which accounted for $19 \%$, and the largest share of exports was in the category of other machinery, with 16.2\%. Additionally, Japan imported agricultural products including beverages and tobacco, making up the fifth-largest share even though the domestic agricultural sector was highly protected. However, Japan exported agricultural products to the EU worth $€ 66,561$ million in 2016, while EU exports to Japan amounted to $€ 10,693$ million in the same year. In total, Japan was able to protect its agricultural sector effectively although its market size based on GDP is approximately one third of the EU's market. On the whole, Japan mainly exported to the EU machinery and appliances and transport equipment, accounting for $65 \%$ of the total export share in the same year, while it imported from the EU mainly products from chemical or allied industries, machinery and alliances, and transport equipment, making up $60.2 \%$ of the total import share. The structure of trade between the two parties based on these trade items seems to be competitive rather than complementary [Deloitte, 2018; Government of Japan, 2017b]. 
Table 7. Japan's Top Five Imports From the EU, 2016

\begin{tabular}{|c|l|c|c|}
\hline Rank & \multicolumn{1}{|c|}{ Products } & Amount (€ Million) & Share of total (\%) \\
\hline 1 & Chemical or allied industries & 13.835 & 23.8 \\
\hline 2 & Machinery and alliances & 10.693 & 18.4 \\
\hline 3 & Transport equipment & 10.470 & 18.0 \\
\hline 4 & Optical and photographic instruments etc. & 5.425 & 9.4 \\
\hline 5 & Foodstuffs, beverages, tobacco & 2.806 & 4.8 \\
\hline
\end{tabular}

Source: [Deloitte, 2018].

Table 8. Japan's Top Five Exports to the EU, 2016

\begin{tabular}{|c|l|c|c|}
\hline Rank & \multicolumn{1}{|c|}{ Products } & Amount (€ Million) & Share of total (\%) \\
\hline 1 & Machinery and appliances & 27.025 & 40.6 \\
\hline 2 & Transport equipment & 16.234 & 24.4 \\
\hline 3 & Chemical or allied industries & 6.101 & 9.1 \\
\hline 4 & Optical and photographic instruments etc. & 5.536 & 8.3 \\
\hline 5 & Plastics, rubber and articles & 2.988 & 4.5 \\
\hline
\end{tabular}

Source: [Deloitte, 2018].

Additionally, the FDI in both parties had been in balance for a long time. In 2016, the EU's accumulated FDI in Japan accounted for $€ 82.8$ billion, while Japan's accumulated FDI in the EU reached $€ 205.7$ billion in the same year. This means that Japan invested in the EU around 2.5 times more than the EU invested in Japan. Although the Japanese investment in the EU is higher than the EU's investment in Japan, the EU's investment based on market size can be regarded as significant [EC, n. d.] (see Fig. 6).

The EU was the second-largest destination for Japanese FDI in 2016, accounting for $22.5 \%$ of the total share. This share was behind the U.S., but ahead of China and ASEAN combined. However, the EU's investment in Japan was overwhelming, with a share of $39.6 \%$ in the same year - much higher than theshare of the U.S. at 27.4\%. As a result, the EU became the largest investor in Japan in 2016 [Bank of Japan, 2016; EC, 2018a] (Fig. 7, 8).

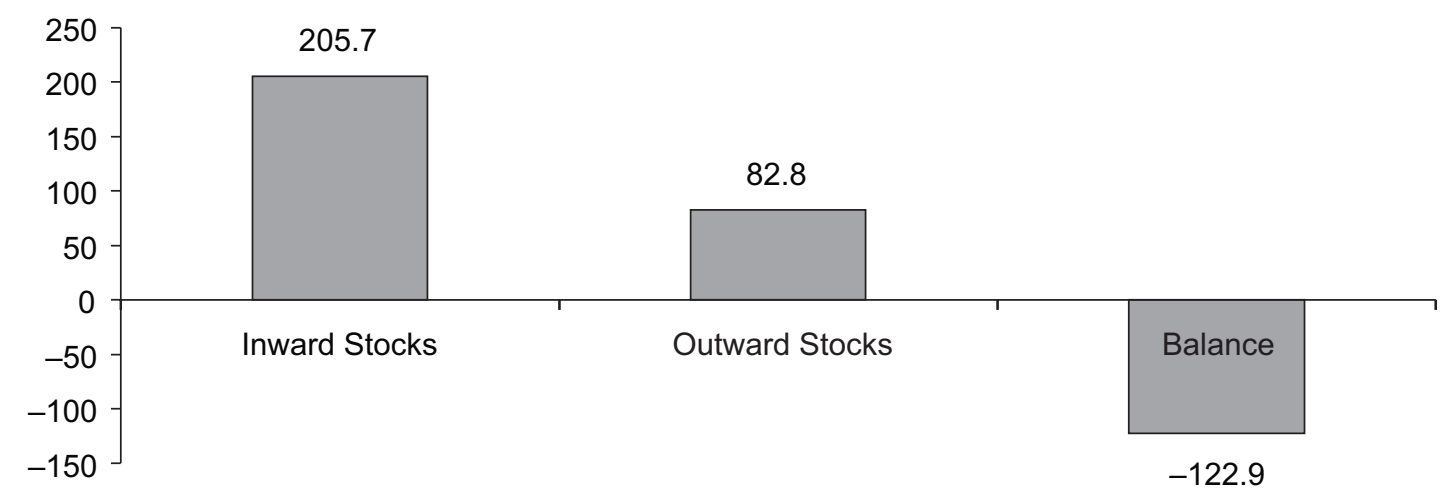

Fig. 6. FDI Between the EU and Japan, 2016 (€ Billion)

Source: [EC, n. d.; 2018]. 


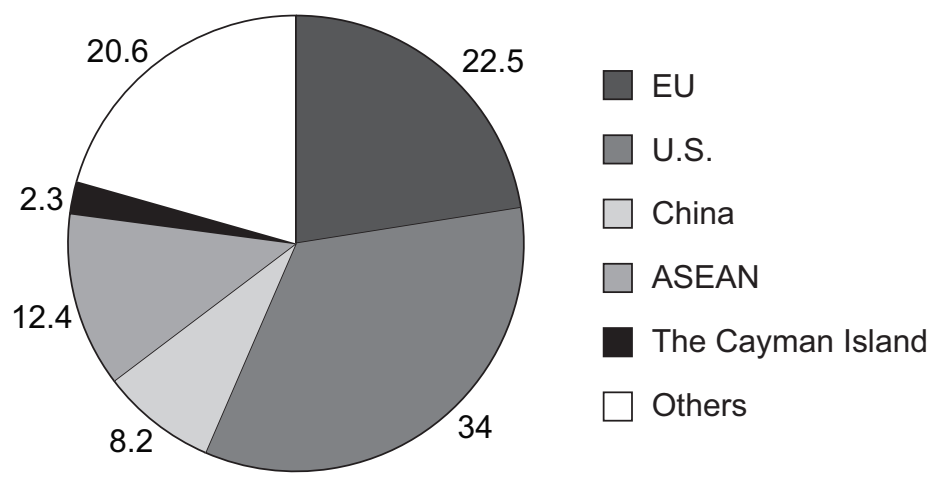

Fig. 7. Japan's Outward FDI, 2016 (\%)

Source: [Bank of Japan, 2016].

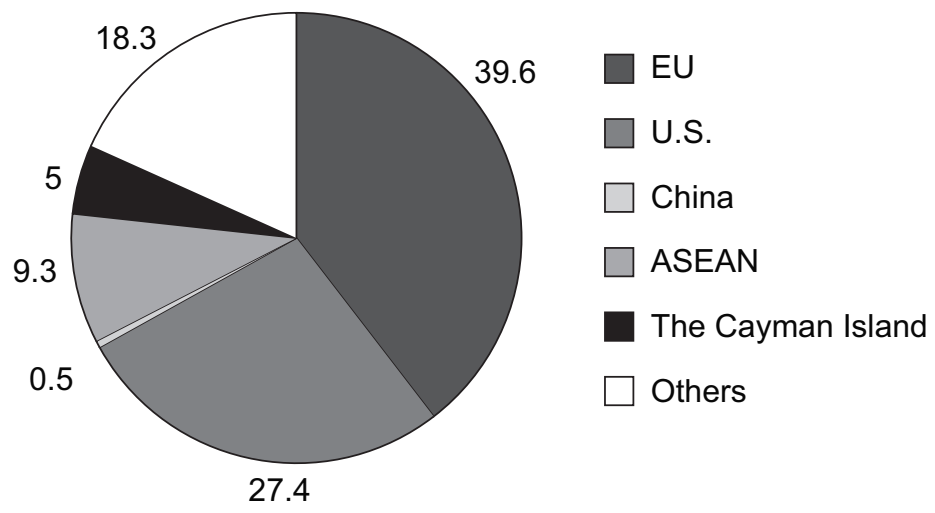

Fig. 8. Japan's Inward FDI, 2016 (\%)

Source: [Bank of Japan, 2016].

\section{Analysis of the EU - Japan FTA}

\section{Targets for the EU - Japan FTA}

On 6 July 2017, the EU and Japan announced an agreement in principle on bilateral free trade after 18 rounds of negotiation over four years. The EC welcomed the approval of the European Parliament in December 2018 and expected the same decision from the Japanese Diet. The EP and the Japanese Diet ratified the text of the EU - Japan Partnership Agreement, which entered into force on 1 February 2019. They characterized the EU - Japan FTA as strategically significant and as sending a strong message in support of trade liberalization that would affect trade and investment in each party. The EU's GDP accounted for $21.8 \%$ of global GDP in 2016, while Japan's GDP reached $6.5 \%$ in the same year. In total, their combined GDP was $28.3 \%$ of global GDP. Additionally, they had a combined population of 638 million and a trade volume worth $\$ 11,887$ million $-8.6 \%$ and $37.1 \%$ of global shares respectively [Akhtar, Williams, 2017; EC, 2018b; Government of Japan, 2017b] (Fig. 9).

The EU and Japan reached agreement in principle (AP) on the three main elements of the EU - Japan FTA. First, the EU - Japan FTA will provide both parties easy accesses to their respective markets to stimulate reciprocal trade and investment activities by forming a 
vast economic zone accounting for approximately one third of the global economy. Second, cooperation between the two parties can be strengthened through the process of establishing various rules, regulations and standards that can serve as a platform for addressing global issues such as international regulations and standards and global warming. Finally, the EU - Japan FTA can tackle U.S. protectionism and support the global free trade system, as well as restart trade strategies after the two parties experienced the failures of the TTIP and TPP mega trade [Sugawara, 2017].

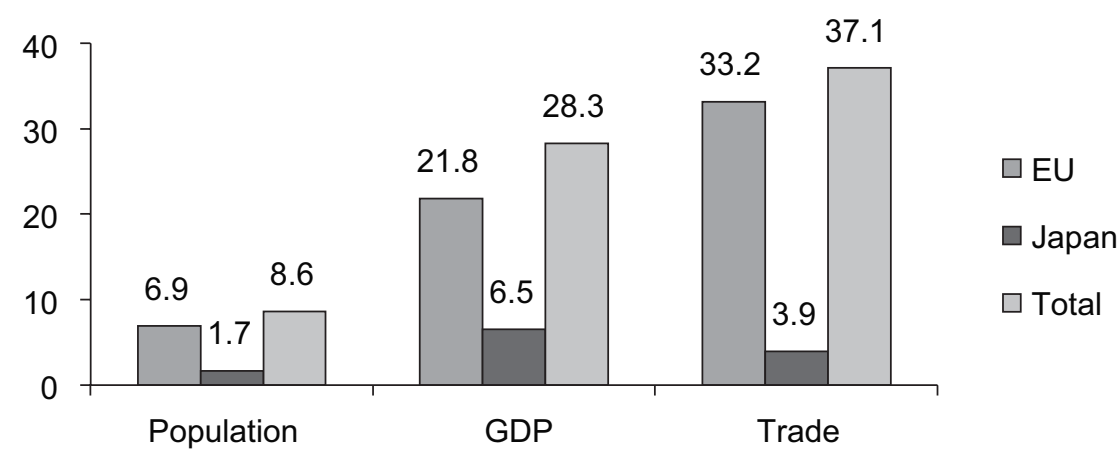

Fig. 9. The EU and Japan's World Share in Population, GDP and Trade, 2016 (\%)

Source: [IMF, 2017; World Bank, 2017].

The EU's main interests in the EU - Japan FTA are to eliminate high customs duties, particularly in the agricultural sector, including beverages. The current Japanese tariffs on beef and cheese (nearly $40 \%$ ), chocolate (30\%) and wines (15\%) are too high for the EU's exporters. Furthermore, the EU is keen to negotiate non-tariff measures on automotive, food safety and chemicals with Japan. The EU also seeks to access Japanese government procurement.

From the Japanese side, its interests are focused on eliminating high customs duties on the automotive sector, chemicals and electronic devices. The current EU tariffs on these products account for $10 \%, 5.5 \%$ and $15 \%$ respectively. Japan is also keen to change the EU's regulatory issues regarding non-tariff measures, and harmonization and mutual recognition of standards and regulations. The former includes technical barriers to trade (TBT) and the latter includes sanitary and phyto-sanitary standards (SPS) as well as genetically modified organisms (GMOs) [Akhtar, Williams, 2017; Business Europe, Keidanren, 2016; Deloitte, 2018; EC, 2018c].

Regarding the elimination of tariffs, the EU liberalized $75 \%$ of its imports from Japan when the EU - Japan FTA entered in force and the ratio will rise nearly $100 \%$ over 15 years. Japan liberalized $91 \%$ of its imports from the EU and $99 \%$ of its imports from the EU will be liberalized over 15 years. The remaining $1 \%$ will be partly liberalized through quotas and tariff reductions. Despite the full tariff elimination, two products - rice and seaweed - will be mutually excluded from tariff liberalization [Sugawara, 2017].

\section{Possible Impacts of the EU - Japan FTA}

Once fully implemented, the impact of the EU - Japan FTA will be significant because high tariff lines will be eliminated. The EU - Japan FTA is described as "a deal of cars for cheese" because the two parties are keen to generate mutual benefits in their sensitive industrial sectors. The EU eliminates $10 \%$ of tariffs on passenger cars, while Japan removes restrictions on imports of dairy, cheese and other agricultural products. The EU - Japan FTA also liberal- 
izes several services sectors such as the temporary movement of business personnel and access to public procurement [Akhtar, Williams, 2017].

In the automotive sector, the EU's imports of automotive products from Japan increased from $€ 9,217$ million in 2013 to $€ 13,036$ million in 2016, while Japan's imports of automotive products from the EU grew from $€ 7,804$ million to $€ 8,946$ million during the same period. The EU's total share of imports in automotive products in 2016 accounted for 19.6\%, while Japan's share in this sector reached $15.4 \%$. This means that Japanese exports of automotive products to the EU market are stronger than those of the EU in the Japanese market. The EU's tariff on passenger cars will decrease over a period of eight years. It will decline from $10 \%$ to $8.8 \%$ in the first year, to $5 \%$ in four years, and will be removed seven years after the FTA entered into force. This means that Japan could gain price advantages in its automotive products in the EU market and could increase its exports with the removal of tariffs on imports of Japanese cars and components (Fig. 10).

In exchange, Japan eliminated many non-tariff measures on the EU's automotive products so that there will be considerable cost savings for European cars exported to Japan. With the tariff reduction and the reduction of non-tariff barriers, the European car industry will be affected by $-0.3 \%$ and $0 \%$ respectively. Additionally, more than $65 \%$ of all Japanese vehicles sold in the EU market are produced in the EU. Japanese car producers maintain 14 production plants and 16 research and development centres in the EU. As a result, removing tariffs on automotive products could boost not only Japanese exports to the EU market, but also production and new employment in Japanese-owned car plants in the EU [Choudhry, Safir, Terzi, 2018; Deloitte, 2018; EC, 2018c].

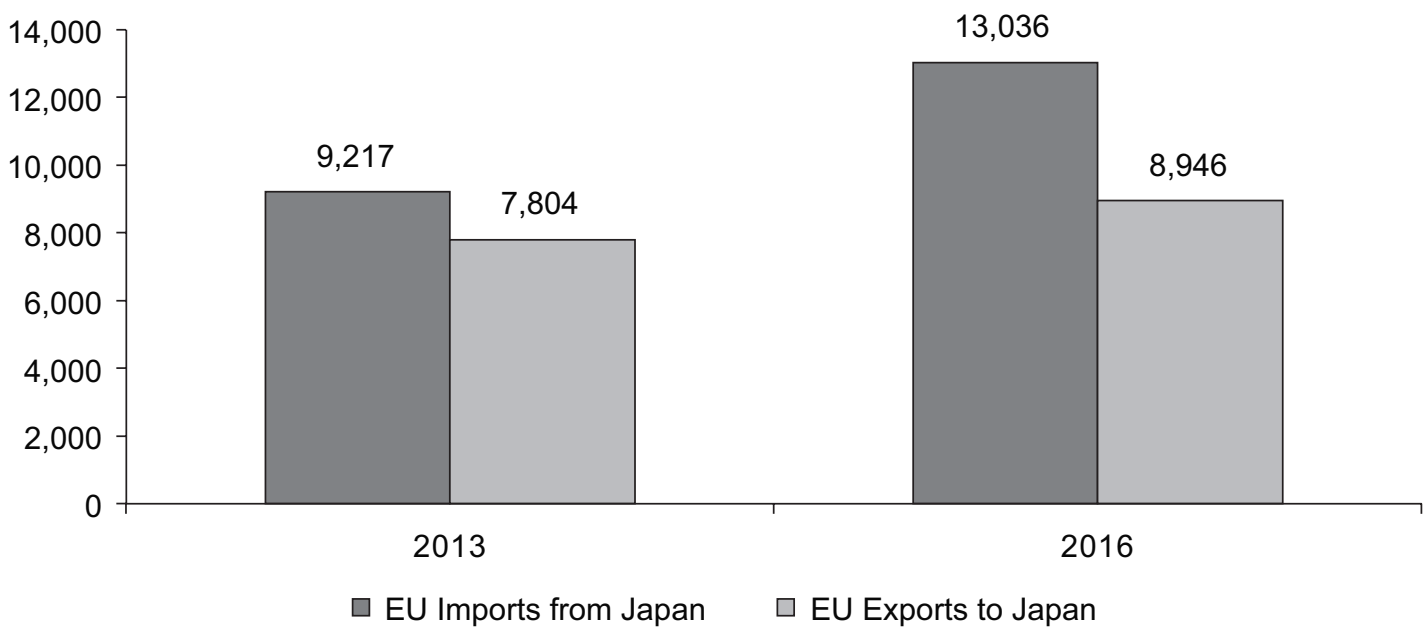

Fig. 10. EU - Japan Trade in Automotive Products, 2013-16 (€ Million)

Source: [Eurostat, 2018].

In the electronics sector, tariff elimination depends on the product although the Information Technology Agreement (ITA) and its expansion have already eroded peak tariffs. As a result, Japan receives the benefits of the ITA without any equivalent staging. As a reciprocity measure, the EU has taken a long staging period of 10 years for footwear despite low exports and the low potential of Japan. It could be a full or a gradual tariff elimination. The tariff on Japanese exports in lamps to the EU will be eliminated from $5.7 \%$ in three years, while the tariff on 
exports of LCD screens will decline from $14 \%$ to $0 \%$ in five years. Japan exported a high volume of machinery and appliances to the EU, which accounted for $40.6 \%$ of its total export share in 2016. The EU's export share of these products to Japan was $18.4 \%$ of its total export share. In trade volume, the EU's exports to Japan increased from €9,430 million in 2013 to $€ 10,693$ million in 2016, while Japanese exports to the EU increased from $€ 26,329$ million to $€ 27,025$ million during the same period. In this sector, the EU experienced its largest trade deficit with Japan [EC, 2018c] (Fig. 11).

After the EU - Japan FTA came into force, customs restrictions for exports of electronics products from both sides were simplified. Moreover, TBT was reduced via the harmonization of different industrial standards and different approaches to dual-use regulations. Additionally, import customs duties for electronic goods and national tariff measures (NTMs) have been reduced so that exports in both parties will increase and more employment can be generated. However, the EU will have a total duty loss double that of Japan's after staging periods of up to 15 years in Non-Agricultural Market Access (NAMA). This net duty loss will be compensated by Japan's concessions in NTMs, government procurement and services [Deloitte, 2018; EC, 2018c; Hilpert, 2017].

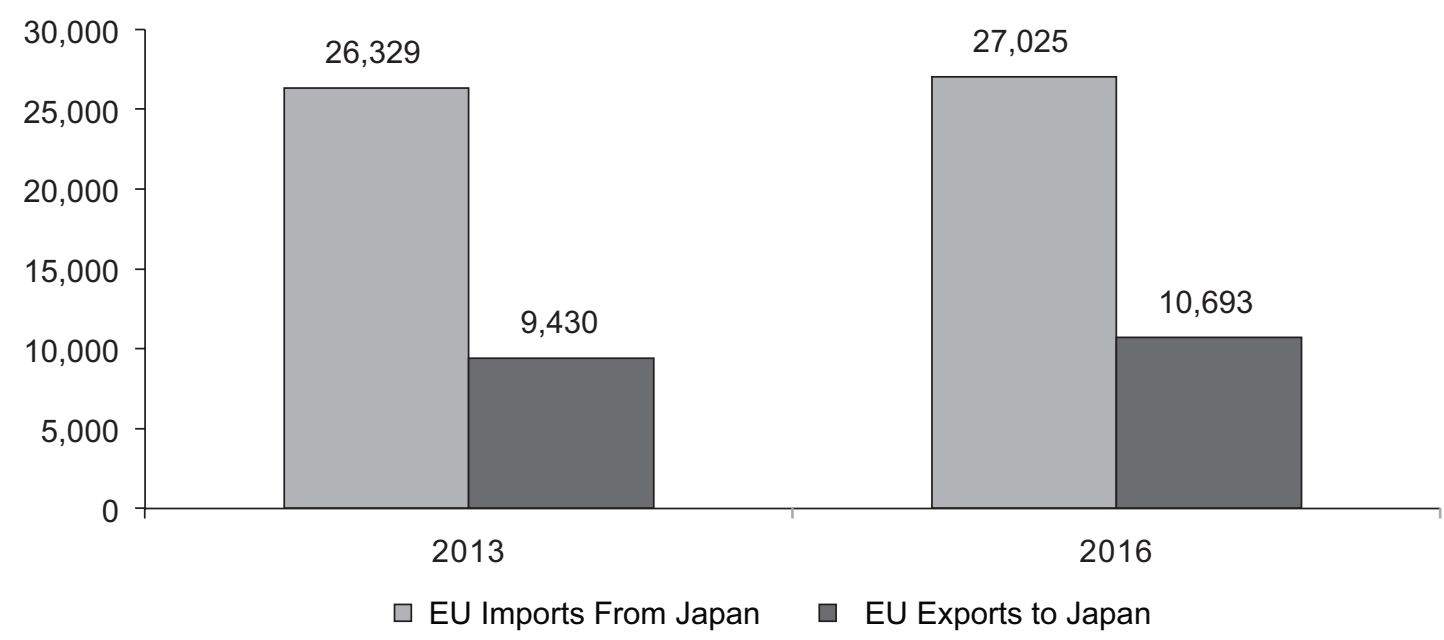

Fig. 11. EU - Japan Trade in Machinery and Appliances, 2013-16 (€ Million)

Source: [Eurostat, 2018].

In the agricultural sector, the pattern of tariff elimination is based on a full or gradual elimination as in the electronics sector. Chocolate and wine to Japan, as well as rice to the EU, will be fully exempt from duties, while the tariff on beef to Japan will be reduced from $40 \%$ to 9\% over 21 years. However, tariff rate quotas (TRQ's) will be used continuously. The EU Japan FTA will strengthen the standard cooperation in SPS and agricultural safeguard measures (ASMs).

Since 2013 the EU's agricultural exports to Japan have increased continuously. Its export volume increased from $€ 5,107$ million in 2013 to $€ 5,774$ million in 2016 , while its imports from Japan increased from $€ 173$ million to $€ 331$ million during the same period. The growth of Japanese agricultural exports has recently increased faster than that of the EU. Japan was the fifth-largest export destination for the EU's agricultural products and foods in 2016, and the elimination of tariffs with the EU - Japan FTA could enhance trade in this sector. While Japan 
is a net importer of food, the EU - Japan FTA could boost the EU's exports to Japan. Japan agreed to liberalize $84 \%$ of all agricultural tariff lines, which covers about $88 \%$ of trade value and around $75 \%$ of duty revenue on average between 2014 and 2016. A study by the Ifo Institute for Economic Research estimated that there would be a positive impact on value added in agrifood industries, with an increase of $0.82 \%$ in the EU [Choudhry, Safir, Terzi, 2018; EC, 2018d; Hilpert, 2017] (Fig. 12).

On the whole, the impact of the EU - Japan FTA could be significant. The long-term GDP growth for the EU is estimated as being up to $0.76 \%$, while Japanese GDP growth could reach $0.29 \%$. Bilateral exports will increase in the range of $13.2-73 \%$ for the EU and $17.1-63 \%$ for Japan according to economic research institutes such as DG Trade, CIAR and Ifo. The aggregated GDP growth generated by the EU - Japan FTA is greater than that created by the EU - Korea FTA because the Japanese economy is over three-times the size of the Korean economy. Additionally, the EU's real wages for less-skilled and skilled labour could increase by $0.68 \%$ and $0.7 \%$ based on CGE modeling in the impact assessment. These wages could increase by $0.45 \%$ and $0.5 \%$ in Japan. Overall, the EU - Japan FTA can be regarded as a win-win approach that generates mutual economic benefits for the two parties. Both parties can realize economic gains even though they have competitive industrial structures instead of complementary ones if both economies are closely interlinked by trade and FDI [Choudhry, Safir, Terzi, 2018; Deloitte, 2018; EC, 2016; Government of Japan, 2017b].

By conservative estimates, the EU - Japan FTA could generate total income gains for the states of the EU worth about $€ 11$ billion per year, and could add welfare effects for Japan of about $€ 9$ billion over 10 years. Among EU states, Germany will gain the largest share with $€ 3.4$ billion, followed by the UK with $€ 1.6$ billion, France with $€ 1.2$ billion and the Netherlands with $€ 0.9$ billion. However, in term of relative gains, the countries with the largest gains will be Ireland with $0.19 \%$, the Netherlands with $0.14 \%$, Luxembourg with $0.13 \%$ and Germany with $0.11 \%$. Even the peripheral EU countries such as Greece, Portugal and Romania will gain up to $0.02 \%$. As a result, all EU countries are expected to benefit, although their relative gains will vary depending on their industrial structure and capacity [Felbermayr et al., 2017].

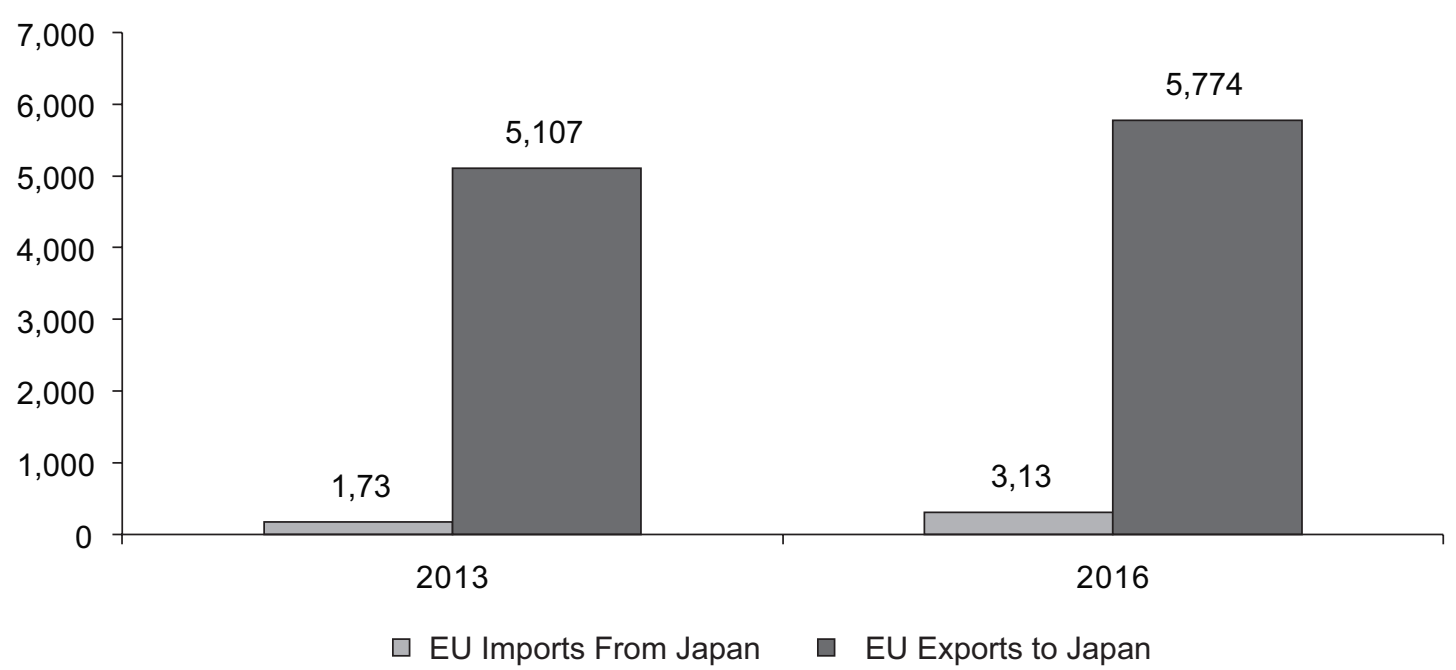

Fig. 12. EU - Japan Trade in Agricultural Products, 2013-16 (€ Million)

Source: [EC, 2018d]. 


\section{Conclusion}

The global trade system has faced a severe dilemma since the Trump administration started to implement protectionism in 2017. In addition, Brexit escalated trade protectionism since 2016. But despite this protectionist turn, a mega FTA deal between the EU and Japan was negotiated in 2012 and completed in 2017.

The European Commission has produced strategy papers in the past two decades focused mainly on achieving economic growth and employment particularly though the Lisbon strategy of 2000 and the current Europe 2020 approach. Additionally, the EC has focused on different parts of the world, including Asia, since the 1990s. However, its vision is constrained by the fact that while the power of the European Commission is high mainly in trade and aid, it remains limited on other issues. In Japan, the strategic goal since the 1950s has been to support the country so that it could thrive under its core alliance with the U.S.; this approach has recently become riskier because a new multipolar global power structure has been formed. Therefore, Japan has needed to galvanize public and semi-public institutions in support of a more clear strategy.

Additionally, the EU was hit by two major economic crises, the global financial crisis and the sovereign debt crisis, that resulted in low economic growth and high unemployment. In order to overcome these economic crises, the EU needed to boost its trade to generate economic growth and new employment. In line with this strategy, the EU set out to complete mega FTAs such as the EU - Japan FTA and the TTIP. In Japan, the economic situation was rather similar due to the global financial crisis and a long-time recession that generated low economic growth. When the Abe administration took office in December 2012, it launched a new economic strategy based on bold monetary policy, flexible financial policy and a growth policy that must revitalize a Japanese stagnant economy. Similar to the EU, Japan's trade policy adopted the mega FTA strategy, including the EU - Japan FTA, the RCEP and the TTP.

In 2012, the EU and Japan began 18 rounds of negotiation, completing their agreement in principle for the EU - Japan FTA in July 2017. The agreement achieved a high degree of trade liberalization. It covers $99 \%$ of tariff lines and $100 \%$ of imports in the EU and $97 \%$ of tariff lines and $99 \%$ of imports in Japan. The two parties agreed to eliminate tariffs and rationalize nontariff barriers, although certain products such as rice and seaweed will be protected at Japan's request. Now that the agreement has entered into force, the EU can export more agricultural products to Japan, while Japan can export more machinery, automotive and electronics products to the EU.

Overall, the EU - Japan FTA generates about $0.76 \%$ GDP growth for the EU and about $0.29 \%$ GDP growth for Japan per year for the next 10 years. Furthermore, it also creates new employment in both parties. In the global economy, the EU - Japan FTA will generate much larger gains than losses and provides a strong signal in support of the free trade system even though the two economies are composed of competitive structures rather than complementary ones. It means that the free trade system is more constructive for the global economy than trade protectionism, and can tackle U.S. protectionism in the global economic system. As a result, it is not only a win-win approach for the EU and Japan, but also for the whole global economy. 


\section{References}

Acemoglu D. (2009) Modern Economic Growth. Princeton: Princeton University Press.

Akhtar S.I., Williams B.R. (2017) The Proposed EU - Japan FTA and Implications for U.S. Trade Policy. CRS Insight IN 10738, Congressional Research Service. Available at: https://fas.org/sgp/crs/row/IN10738.pdf (accessed 10 May 2018).

Baldwin R. (2007) Managing the Noodle Bowl: The Fragility of East Asian Regionalism. ADB Working Paper Series on Regional Economic Integration No 7, Asian Development Bank. Available at: https://www.adb.org/ sites/default/files/publication/28464/wp07-baldwin.pdf (accessed 18 April 2019).

Baldwin R. (2011) Sequencing Regionalism: Theory, European Practice, and Lessons for Asia. ADB Working Paper Series on Regional Economic Integration No 80, Asian Development Bank. Available at: https://www. adb.org/sites/default/files/publication/28886/wp80-baldwin-sequencing-regionalism.pdf (accessed 18 April 2019).

Bank of Japan (BOJ) (2016) Japan's Balance of Payments Statistics and International Investment Position for 2016. Balance of Payments Division. Available at: https://www.boj.or.jp/en/statistics/br/bop_06/bop2016a. pdf (accessed 10 May 2018).

Bhagwati J. (2009) Does the U.S Need a New Trade Policy? Journal of Policy Modeling, vol. 31, no 4, pp. 509-14. Available at: https://www.researchgate.net/publication/319551057_IndiaTrade_Development and_New_Trade_Theory (accessed 10 May 2018).

Bown C.P., Kolb M. (2018) Trump's Trade War Timeline: An Up-to-Date Guide. Peterson Institute for International Economics. Available at: https://piie.com/blogs/trade-investment-policy-watch/trump-trade-warchina-date-guide (accessed 18 April 2019).

Bown C.P., Jung E.J., Lu Z. (2018) Trump and China Formalize Tariffs on $\$ 260$ Billion of Imports and Look Ahead to Next Phase. Peterson Institute for International Economics. Available at: https://piie.com/blogs/ trade-investment-policy-watch/trump-and-china-formalize-tariffs-260-billion-imports-and-look (accessed 21 September 2018).

Bradford S., Grieco P., Hufbauer G.C. (2006) The Payoff to America From Globalisation. The World Economy, vol. 29, no 7, pp. 893-917.

Broda C.M., Weinstein D.E. (2006) Globalization and the Gains From Variety. The Quarterly Journal of Economics, vol. 121, no 2, pp. 541-85.

Business Europe, Keidanren Policy \& Action (2016) Joint Statement for EU - Japan Regulatory Cooperation. 13 December. Available at: https://www.businesseurope.eu/sites/buseur/files/media/position_papers/ rex/2016-12-13_be-keidanren_statement_on_eu-jap_regulatory_cooperation.pdf (accessed 11 May 2018).

Choudhry S., Safir A., Terzi A. (2018) The EU Japan Economic Partnership Agreement. Brussels: Bruegel. Available at: http://bruegel.org/2018/10/the-eu-japan-economic-partnership-agreement/ (accessed 9 June 2019).

Deloitte (2018) The New EU Japan EPA: How Can Your Company Leverage Improved Trade Cooperation and Market Access? Available at: https://www2.deloitte.com/content/dam/Deloitte/be/Documents/tax/ PPT/EU\%20Japan\%20webinar\%2002\%2002\%202018\%20final\%20slide\%20deck\%20for\%20sharing.pdf (accessed 18 April 2019).

de Prado C. (2014) Prospects for the EU - Japan Strategic Partnership: A Global Multi-level and SWOT Analysis. European University Institute. Available at: https://www.eu-japan.eu/sites/default/files/publications/docs/eujpstrategicpartnership.pdf (accessed 18 April 2019).

Dyrsdale P., Armstrong S. (2014) Japan's Foreign Economic Policy Strategies and Economic Performance. Working Paper Series No 340, Center on Japanese Economy and Business, Columbia University. Available at: https://academiccommons.columbia.edu/doi/10.7916/D808640Q (accessed 1 June 2019).

Edwards J. (2018) Trump's Trade War Could Destroy 4\% of Global Trade: 'The Threat to World Growth is Significant.' Business Insider, 4 July. Available at: https://www.businessinsider.com/statistics-trump-tradewar-global-trade-world-growth-gdp-2018-7 (accessed 17 September 2018). 
European Commission (EC) (n. d.) Countries and Regions: Japan. Available at: http://ec.europa.eu/trade/ policy/countries-and-regions/countries/japan/ (accessed 2 June 2019).

European Commission (EC) (2016) Trade Sustainability Impact Assessment of the Free Trade Agreement Between the European Union and Japan: Final Report. Available at: http://trade.ec.europa.eu/doclib/docs/2016/ may/tradoc_154522.pdf (accessed 12 May 2018).

European Commission (EC) (2017) Report on the Implementation of the Trade Policy Strategy Trade for All: Delivering a Progressive Trade Policy to Harness Globalisation. COM (2017) 491 Final. Available at: https:// www.eumonitor.eu/9353000/1/j9vvik7m1c3gyxp/vkhlg270lpyp (accessed 18 April 2019).

European Commission (EC) (2018a) European Union, Trade in Goods With Japan. Available at: https://webgate.ec.europa.eu/isdb_results/factsheets/country/details_japan_en.pdf (accessed 18 April 2019).

European Commission (EC) (2018b) EU - Japan Trade Agreement on Track to Enter Into Force in February 2019. 12 December. Available at: http://trade.ec.europa.eu/doclib/press/index.cfm?id=1954 (accessed 9 February 2019).

European Commission (EC) (2018c) The Economic Impact of the EU - Japan Economic Partnership Agreement (EPA): An Analysis Prepared by the European Commission's Directorate-General for Trade. Available at: http://trade.ec.europa.eu/doclib/docs/2018/july/tradoc_157115.pdf (accessed 10 February 2019).

European Commission (EC) (2018d) Agri-Food Trade Statistical Factsheet: European Union - Japan. Directorate-General for Agriculture and Rural Development. Available at: https://ec.europa.eu/agriculture/sites/ agriculture/files/trade-analysis/statistics/outside-eu/countries/agrifood-japan_en.pdf (accessed 12 February 2018).

European Political Strategy Centre (EPSC) (2017) EU - Japan: Advanced Economies Shaping the Next Stage of Inclusive Globalisation. EPSC Brief, European Political Strategy Centre. Available at: https://ec.europa. eu/epsc/sites/epsc/files/epsc-brief-eu-japan-economic-partnership-agreement.pdf (accessed 18 April 2019).

Eurostat (2017) Annual Activity Report 2017. Brussels: Eurostat. Available at: https://ec.europa.eu/info/publications/annual-activity-report-2017-eurostat_en (accessed 18 April 2019).

Eurostat (2018) Eurostat Comext Statistical Regime 4. Available at: https://ec.europa.eu/eurostat/en/web/ products-statistical-books/-/KS-01-18-656 (accessed 9 June 2019).

Felbermayr G., Kimura F., Okubo T., Steininger M., Yalcin E. (2017) On the Economics of an EU - Japan Free Trade Agreement. Ifo Forschungsberichte 86, Ifo Institute. Available at: https://www.cesifo-group.de/ DocDL/ifo_Forschungsberichte_86_2017_Felbermayr_etal_eu-japanFreeTrade.pdf (accessed 18 April 2019).

Feenstra R.C., Mandel B.R., Reinsdorf M.B., Slaughter M. (2009) Effects of Terms of Trade Gains and Tariff Changes on the Measurement of U.S. Productivity Growth. NBER Working Paper No 15592, National Bureau of Economic Research. Available at: https://www.nber.org/papers/w15592 (accessed 18 April 2019).

Freund C., Ferrantino M.J., Maliszewska M., Ruta M. (2018) Impacts on Global Trade and Income of Current Trade Disputes. MTI Practice Note No 2, World Bank Group. Available at: http://documents.worldbank.org/ curated/en/685941532023153019/Impacts-on-Global-Trade-and-Income-of-Current-Trade-Disputes (accessed 18 April 2019).

Gomory R., Baumol W. (2009) Globalization: Country and Company Interests in Conflict. Journal of Policy Modeling, vol. 31, no 3, pp. 540-55.

Government of Japan (2017) Japan - EU EPA. Ministry of Foreign Affairs. Available at: http://www.mofa. go.jp/files/000013835.pdf (accessed 9 May 2018).

Grace A. (2018) China and America May Be Forging a New Economic Order. The Atlantic, 20 September. Available at: https://www.theatlantic.com/international/archive/2018/09/china-trade-war-trump/570880/ (accessed 21 September 2018).

Gstöhl S. (2016) 'Trade for All' - All for Trade? The EU's New Strategy. College of Europe Policy Brief No 3.16. Available at: http://aei.pitt.edu/93101/1/gstohl_cepob_3-16.pdf (accessed 3 May 2018).

Hilpert H.G. (2017) The Japan - EU Economic Partnership Agreement. SWP Comments 49, Stifung Wissenschaft und Politik, German Institute for International and Security Affairs. Available at: https://www.swpberlin.org/en/publication/the-japan-eu-economic-partnership-agreement/ (accessed 18 April 2019). 
International Monetary Fund (IMF) (2017) World Economic Outlook Database October. Washington DC: IMF.

International Monetary Fund (IMF) (2018) World Economic Outlook Update, 16 July. Available at: https:// www.imf.org/en/Publications/WEO/Issues/2018/07/02/world-economic-outlook-update-july-2018 (accessed 18 April 2019).

Jun K. (2018) U.S., South Korea Strike Trade Deal: Seoul Exempt From Steel Tariffs. The Wall Street Journal, 25 March. Available at: https://www.wsj.com/articles/u-s-south-korea-amend-trade-deal-seoul-exemptfrom-steel-tariffs-1522032055 (accessed 20 September 2018).

Krugman P.R. (1979) Increasing Returns, Monopolistic Competition, and International Trade. Journal of International Economics, vol. 9, no 4, pp. 469-79.

Krugman P.R., Obstfeld M. (2009) International Economics. Boston: Pearson, Addison-Wesley.

Lawrence R.Z. (2018) How the United States Should Confront China Without Threatening the Global Trading System. PIIE Policy Brief No 18-17, Peterson Institute for International Economics. Available at: https:// piie.com/publications/policy-briefs/how-united-states-should-confront-china-without-threatening-global (accessed 18 April 2019).

Lewer J.J., van den Berg H. (2007) International Trade and Economic Growth. Armonk: M.E. Sharpe.

Martin W. (2018) A Troubling Lesson From the 1930s Suggests Trump's Trade War Will Damage the World for Decades. Business Insider, 15 July. Available at: https://www.businessinsider.com/oxford-economics-trumptrade-war-protectionism-great-depression-2018-7 (accessed 15 September 2018).

McLarty Associates (2018) Trade Update: Deepening of the U.S. - China Trade War Continued. July 11. Available at: https://maglobal.com/mclarty-trade-update-deepening-of-the-us-china-trade-war-continued/ (accessed 17 September 2018).

Mitsuyo A., Fukunari K. (2008) Japanese FTA/EPA Strategies and Agricultural Protection. Keio Business Review, vol. 44, pp. 1-25. Available at: file:///C:/Users/\%EB\%B0\%95\%EC\%83\%81\%EC\%B2\%A0/Downloads/AA00260481-20080000-0001.pdf (accessed 9 June 2019).

Ng T., Chung K. (2018) Trade Conflict Between China and the United States and Its Impact on Hong Kong's Economy. Hong Kong: Research Office, Legislative Council Secretariat. Available at: https://www.legco.gov. $\mathrm{hk} /$ research-publications/english/1718in14-trade-conflict-between-china-and-the-united-states-and-its-impact-on-hong-kongs-economy-20180717-e.pdf (accessed 9 February 2019).

Office of the United States Trade Representative (USTR) (2018) USTR Finalizes Tariffs on \$200 Billion of Chinese Imports in Response to China's Unfair Trade Practices. Press Release, 18 September. Available at: https://ustr.gov/about-us/policy-offices/press-office/press-releases/2018/september/ustr-finalizes-tariffs-200 (accessed 20 September 2018).

O’Rourke K.H., Williamson J.G. (2001) Globalization and History: The Evolution of Nineteenth Century Atlantic Economy. Cambridge: The MIT Press.

Ortiz-Ospina E., Beltekian D., Roser M. (2018) Trade and Globalization. Available at: https://ourworldindata. org/trade-and-globalization (accessed 8 June 2019).

Park S.-C. (2017) Can Trade Help Overcome Economic Crisis? Implications for Northeast Asia Creating a Regional FTA between Korea, China, and Japan and Mega FTAs Such as RCEP and TPP. International Organisations Research Journal, vol. 12, no 2, pp. 104-28.

Park S.-C., Pasierbiak P. (2018) Japan's Role in East Asian Economic Regionalism. Institutions and Economies, vol. 10, no 2, pp. 121-45.

Partington R. (2018) IMF Warns Trump Trade War Could Cost Global Economy \$430bn. The Guardian, 16 July. Available at: https://www.theguardian.com/business/2018/jul/16/imf-trump-trade-war-global-economy-us-tariff-weo (accessed 23 September 2018).

Rosen H.F. (2008) Strengthening Trade Adjustment Assistance. Policy Brief 08-2, Peterson Institute for International Economics. Available at: https://piie.com/sites/default/files/publications/pb/pb08-2.pdf (accessed 1 June 2019). 
Samuelson P. (2004) Where Ricardo and Mill Rebut and Confirm Arguments of Mainstream Economists Supporting Globalization. Journal of Economic Perspectives, vol. 18, no 3, pp. 135-146.

Sugawara J. (2017) Significance of the Japan-EU EPA: The Agreement in Principle: Restart of Japan's Trade Strategy. Mizuho Economic Outlook and Analysis, 12 July. Available at: https://www.mizuho-ri.co.jp/publication/research/pdf/eo/MEA170814.pdf (accessed 11 May 2018).

Tatsushi O. (2002) An Approach towards Japan's FTA Policy. Working Paper Series 01-02 No 4, IDE APEC Study Center. Available at: https://www.ide.go.jp/library/English/Publish/Download/Apec/pdf/2001_16.pdf (accessed 1 June 2019).

Yamamoto Y., Kikuchi T. (1998) Japan's Approach to APEC and Regime Creation in the Asia Pacific. AsiaPacific Crossroads: Regime Creation and the Future of APEC (V.K. Aggarwal, C.E. Morrison (eds)). New York: St Martin's Press.

World Bank (2017) World Development Indicators, 21 November. Washington DC: World Bank.

World Trade Organization (WTO) (2018) World Trade Statistical Review 2018, Geneva: WTO. 


\title{
Торговый протекционизм как ахиллесова пята международного сотрудничества и соглашение о свободной торговле ЕC - Япония как мера по борьбе с ним ${ }^{1}$
}

\author{
С. - - Пак
}

Пак Санг-Чул - профессор Высшей школы наукоемких технологий и энергетики Политехнического университета Республики Корея; 2121 Jeongwang-Dong, Siheung-City, Kyonggi-Do, 429-793, Korea; E-mail: scpark@kpu.ac.kr

\begin{abstract}
Политика торгового протекционизма, реализуемая администрацией президента Дональда Трампа в США, в последние годы усилилась. Власти США закрывают глаза на Транстихоокеанское партнерство (ТТП) - инициативу, которая была «подхвачена» премьер-министром Японии Синдзо Абэ после выхода из нее США в 2018 г. В настоящее время торговая война между Китаем и США, а также Европейским союзом (ЕС) и США продолжается. Никто не может точно оценить, каким образом она трансформирует мировую экономику. В некоторых случаях торговый протекционизм рассматривается как ахиллесова пята глобального экономического сотрудничества. Несмотря на распространенные протекционистские настроения, в глобальной экономике остаются сторонники свободной торговли. ЕС и Япония начали переговоры по вопросу заключения соглашения о свободной торговле в 2012 г. Соглашение было финализировано в декабре 2017 г. после 18 раундов переговоров. После юридической верификации и перевода (на языки ЕС. - Примеч. пер.) Европейская комиссия представила Соглашение на одобрение в Европарламент и в национальные органы ЕС. Япония, страна с высокоразвитой экономикой и ключевой участник глобальной торговой и инвестиционной системы, является одним из наиболее значимых партнеров для ЕС. Соглашение о свободной торговле между ЕС и Японией может создать основу для активного экономического сотрудничества стран-участнии, на которые в 2017 г. приходилось $30 \%$ глобального ВВП. Кроме того, торговое соглашение между ЕС и Японией может устранить многие барьеры и способствовать формированию правил глобальной торговли, в основу которых будут положены принципы свободы и общих ценностей. Соглашение также доказывает, что две крупнейшие экономики мира отвергают протекционизм, который развивался с момента глобального финансового кризиса в 2008 г. и достиг апогея после прихода к власти в США в 2017 г. Д. Трампа. В данной статье исследуется, как ССТ ЕС - Япония может способствовать экономическому росту и какие выгоды оно принесет для обеих сторон. Автор также анализирует, каким секторам экономики ССТ принесет наибольшие выгоды. Наконеи, автор пытается оценить воздействие соглашения на состояние глобальной торговли.
\end{abstract}

Ключевые слова: торговый протекционизм; торговые барьеры; правила глобальной торговли; соглашение о свободной торговле (ССТ); экономический рост; ЕС; Япония; США

Для цитирования: Пак С.-Ч. (2019) Торговый протекционизм как ахиллесова пята международного сотрудничества и соглашение о свободной торговле ЕС - Япония как мера по борьбе с ним // Вестник международных организаций. Т. 14. № 2. С. 163-191 (на русском и английском языках). DOI: 10.17323/1996-78452019-02-08.

\section{Источники}

Acemoglu D. (2009) Modern Economic Growth. Princeton: Princeton University Press.

Akhtar S.I., Williams B.R. (2017) The Proposed EU - Japan FTA and Implications for U.S. Trade Policy. CRS Insight IN 10738, Congressional Research Service. Режим доступа: https://fas.org/sgp/crs/row/IN10738.pdf (дата обращения: 10.05.2019).

\footnotetext{
${ }^{1}$ Статья поступила в редакцию в октябре 2018 г.
} 
Baldwin R. (2007) Managing the Noodle Bowl: The Fragility of East Asian Regionalism. ADB Working Paper Series on Regional Economic Integration No 7, Asian Development Bank. Режим доступа: https://www.adb. org/sites/default/files/publication/28464/wp07-baldwin.pdf (дата обращения: 18.04.2019).

Baldwin R. (2011) Sequencing Regionalism: Theory, European Practice, and Lessons for Asia. ADB Working Paper Series on Regional Economic Integration No 80, Asian Development Bank. Режим доступа: https://www.adb.org/ sites/default/files/publication/28886/wp80-baldwin-sequencing-regionalism.pdf (дата обращения: 18.04.2019).

Bank of Japan (BOJ) (2016) Japan's Balance of Payments Statistics and International Investment Position for 2016. Balance of Payments Division. Режим доступа: https://www.boj.or.jp/en/statistics/br/bop_06/ bop2016a.pdf (дата обращения: 10.05.2019).

Bhagwati J. (2009) Does the U.S Need a New Trade Policy? // Journal of Policy Modeling. Vol. 31. No. 4. P. 509-514. Режим доступа: https://www.researchgate.net/publication/319551057_IndiaTrade_ Development_and_New_Trade_Theory (дата обращения: 10.05.2019).

Bown C.P., Kolb M. (2018) Trump's Trade War Timeline: An Up-to-Date Guide. Peterson Institute for International Economics. Режим доступа: https://piie.com/blogs/trade-investment-policy-watch/trump-tradewar-china-date-guide (дата обращения: 18.04.2019).

Bown C.P., Jung E.J., Lu Z. (2018) Trump and China Formalize Tariffs on $\$ 260$ Billion of Imports and Look Ahead to Next Phase. Peterson Institute for International Economics. Режим доступа: https://piie.com/blogs/ trade-investment-policy-watch/trump-and-china-formalize-tariffs-260-billion-imports-and-look(дата обращения: 21.09.2018).

Bradford S., Grieco P., Hufbauer G.C. (2006) The Payoff to America From Globalisation // The World Economy. Vol. 29. No. 7. P. 893-917.

Broda C.M., Weinstein D.E. (2006) Globalization and the Gains from Variety // The Quarterly Journal of Economics. Vol. 121. No. 2. P. 541-85.

Business Europe, Keidanren Policy \& Action (2016) Joint Statement for EU - Japan Regulatory Cooperation. 13 December. Режим доступа: https://www.businesseurope.eu/sites/buseur/files/media/position_papers/ rex/2016-12-13_be-keidanren_statement_on_eu-jap_regulatory_cooperation.pdf (дата обращения: 11.05.2019).

Choudhry S., Safir A., Terzi A. (2018) The EU - Japan Economic Partnership Agreement. Brussels: Bruegel. Режим доступа: http://bruegel.org/2018/10/the-eu-japan-economic-partnership-agreement/ (дата обращения: 10.05.2019).

Deloitte (2018) The New EU - Japan EPA: How Can Your Company Leverage Improved Trade Cooperation and Market Access? Режим доступа: https://www2.deloitte.com/content/dam/Deloitte/be/Documents/ tax/PPT/EU\%20Japan\%20webinar\%2002\%2002\%202018\%20final\%20slide\%20deck\%20for\%20sharing.pdf (дата обращения: 18.04.2019).

Dyrsdale P., Armstrong S. (2014) Japan's Foreign Economic Policy Strategies and Economic Performance. Working Paper Series No 340, Center on Japanese Economy and Business, Columbia University. Режим доступа: https://academiccommons.columbia.edu/doi/10.7916/D808640Q (дата обращения: 01.06.2019).

Edwards J (2018) Trump's Trade War Could Destroy 4\% of Global Trade: 'The Threat to World Growth is Significant' // Business Insider. 4 July. Режим доступа: https://www.businessinsider.com/statistics-trumptradewar-global-trade-world-growth-gdp-2018-7 (дата обращения: 17.09.2018).

European Commission (EC) (s. a.) Countries and Regions: Japan. Режим доступа: http://ec.europa.eu/ trade/policy/countries-and-regions/countries/japan/ (дата обращения: 02.06.2019).

European Commission (EC) (2016) Trade Sustainability Impact Assessment of the Free Trade Agreement between the European Union and Japan: Final Report. Режим доступа: http://trade.ec.europa.eu/doclib/ docs/2016/may/tradoc_154522.pdf (дата обращения: 12.05.2019).

European Commission (EC) (2017) Report on the Implementation of the Trade Policy Strategy Trade for All: Delivering a Progressive Trade Policy to Harness Globalisation. COM(2017)491 Final. Режим доступа: https://www.eumonitor.eu/9353000/1/j9vvik7m1c3gyxp/vkhlg270lpyp (дата обращения: 18.04.2019).

European Commission (EC) (2018a) European Union, Trade in Goods with Japan. Режим доступа: https:// webgate.ec.europa.eu/isdb_results/factsheets/country/details_japan_en.pdf (дата обращения: 18.04.2019).

European Commission (EC) (2018b) EU - Japan Trade Agreement on Track to Enter into Force in February 2019. 12 December. Режим доступа: http://trade.ec.europa.eu/doclib/press/index.cfm?id=1954 (дата обращения: 09.02.2019). 
European Commission (EC) (2018c) The Economic Impact of the EU - Japan Economic Partnership Agreement (EPA): An Analysis Prepared by the European Commission's Directorate-General for Trade. Режим доступа: http://trade.ec.europa.eu/doclib/docs/2018/july/tradoc_157115.pdf (дата обращения: 10.02.2019).

European Commission (EC) (2018d) Agri-Food Trade Statistical Factsheet: European Union-Japan. Directorate General for Agriculture and Rural Development. Режим доступа: https://ec.europa.eu/agriculture/sites/ agriculture/files/trade-analysis/statistics/outside-eu/countries/agrifood-japan_en.pdf (дата обращения: 18.04.2019).

European Political Strategy Centre (EPSC) (2017) EU - Japan: Advanced Economies Shaping the Next Stage of Inclusive Globalisation. EPSC Brief, European Political Strategy Centre. Режим доступа: https://ec.europa.eu/ epsc/sites/epsc/files/epsc-brief-eu-japan-economic-partnership-agreement.pdf (дата обращения: 18.04.2019).

Eurostat (2017) Annual Activity Report 2017. Brussels: Eurostat. Режим доступа: https://ec.europa.eu/info/ publications/annual-activity-report-2017-eurostat_en (дата обращения: 14.06.2019).

Eurostat (2018) Eurostat Comext Statistical Regime 4. Режим доступа: https://ec.europa.eu/eurostat/en/ web/products-statistical-books/-/KS-01-18-656 (дата обращения: 09.06.2019).

Felbermayr G., Kimura F., Okubo T., Steininger M., Yalcin E. (2017) On the Economics of an EU - Japan Free Trade Agreement. Ifo Forschungsberichte 86, Ifo Institute. Режим доступа: https://www.cesifo-group. de/DocDL/ifo_Forschungsberichte_86_2017_Felbermayr_etal_EU-JapanFreeTrade.pdf (дата обращения: 18.04.2019).

Feenstra R.C., Mandel B.R., Reinsdorf M.B., Slaughter M. (2009) Effects of Terms of Trade Gains and Tariff Changes on the Measurement of U.S. Productivity Growth. NBER Working Paper No 15592, National Bureau of Economic Research. Режим доступа: https://www.nber.org/papers/w15592 (дата обращения: 18.04.2019).

Freund C., Ferrantino M.J., Maliszewska M., Ruta M. (2018) Impacts on Global Trade and Income of Current Trade Disputes. MTI Practice Note No 2, World Bank Group. Режим доступа: http://documents.worldbank. org/curated/en/685941532023153019/Impacts-on-Global-Trade-and-Income-of-Current-Trade-Disputes (дата обращения: 18.04.2019).

Gomory R., Baumol W. (2009) Globalization: Country and Company Interests in Conflict // Journal of Policy Modeling. Vol. 31. No. 3. P. 540-55.

Government of Japan (2017) Japan - EU EPA. Ministry of Foreign Affairs. Режим доступа: http://www. mofa.go.jp/files/000013835.pdf (дата обращения: 09.05.2018).

Grace A. (2018) China and America May Be Forging a New Economic Order. The Atlantic. 20 September. Peжим доступа: https://www.theatlantic.com/international/archive/2018/09/china-trade-war-trump/570880/ (дата обращения: 21.05.2018).

Gstohl S. (2016) 'Trade for All' - All for Trade? The EU's New Strategy. College of Europe Policy Brief No 3.16. Режим доступа: http://aei.pitt.edu/93101/1/gstohl_cepob_3-16.pdf (дата обращения: 03.05.2019).

Hilpert H.G. (2017) The Japan - EU Economic Partnership Agreement. SWP Comments 49, Stifung Wissenschaft und Politik, German Institute for International and Security Affairs. Режим доступа: https://www.swpberlin.org/en/publication/the-japan-eu-economic-partnership-agreement/ (дата обращения: 18.04.2019).

International Monetary Fund (IMF) (2017) World Economic Outlook Database Oct. Washington DC: IMF.

International Monetary Fund (IMF) (2018) World Economic Outlook Update. 16 July. Режим доступа: https://www.imf.org/en/Publications/WEO/Issues/2018/07/02/world-economic-outlook-update-july-2018 (дата обращения: 18.04.2019).

Jun K. (2018) U.S., South Korea Strike Trade Deal: Seoul Exempt from Steel Tariffs // The Wall Street Journal. 25 March. Режим доступа: https://www.wsj.com/articles/u-s-south-korea-amend-trade-deal-seoul-exemptfrom-steel-tariffs-1522032055 (дата обращения: 20.09.2018).

Krugman P.R. (1979) Increasing Returns, Monopolistic Competition, and International Trade // Journal of International Economics. Vol. 9. No. 4. Р. 469-79. Режим доступа: https://doi.org/10.1016/00221996(79)90017-5 (дата обращения: 21.05.2018).

Krugman P.R., Obstfeld M. (2009) International Economics. Boston: Pearson, Addison-Wesley.

Lawrence R.Z. (2018) How the United States Should Confront China without Threatening the Global Trading System. PIIE Policy Brief No 18-17, Peterson Institute for International Economics. Режим доступа: https:// 
piie.com/publications/policy-briefs/how-united-states-should-confront-china-without-threatening-global (дата обращения: 18.04.2019).

Lewer J.J., van den Berg H. (2007) International Trade and Economic Growth. Armonk: M.E. Sharpe.

Martin W. (2018) A Troubling Lesson from the 1930s Suggests Trump's Trade War Will Damage the World for Decade // Business Insider. 15 July. Режим доступа: https://www.businessinsider.com/oxford-economicstrump-trade-war-protectionism-great-depression-2018-7 (дата обращения: 15.09.2019).

McLarty Associates (2018) Trade Update: Deepening of the U.S. - China Trade War Continued. July 11. Режим доступа: https://maglobal.com/mclarty-trade-update-deepening-of-the-us-china-trade-war-continued/ (дата обращения: 17.09.2018).

Mitsuyo A., Fukunari K. (2008) Japanese FTA/EPA Strategies and Agricultural Protection // Keio Business Review. Vol. 44. P. 1-25. Режим доступа: file://C:/Users/\%ЕВ\%B0\%95\%ЕC\%83\%81\%ЕC\%B2\%A0/ Downloads/AA00260481-20080000-0001.pdf (дата обращения: 13.06.2019).

Ng T., Chung K. (2018) Trade Conflict between China and the United States and Its Impact on Hong Kong's Economy. Hong Kong: Research Office, Legislative Council Secretariat. Режим доступа: https://www.legco. gov.hk/research-publications/english/1718in14-trade-conflict-between-china-and-the-united-states-anditsimpact-on-hong-kongs-economy-20180717-e.pdf (дата обращения: 09.02.2019).

Office of the United States Trade Representative (USTR) (2018) USTR Finalizes Tariffs on \$200 Billion of Chinese Imports in Response to China's Unfair Trade Practices. Press Release. 18 September. Режим доступа: https://ustr.gov/about-us/policy-offices/press-office/press-releases/2018/september/ustr-finalizestariffs-200 (дата обращения: 20.09.2018).

O'Rourke K.H., Williamson J.G. (2001) Globalization and History: The Evolution of Nineteenth Century Atlantic Economy. Cambridge: The MIT Press.

Ortiz-Ospina E., Beltekian D., Roser M. (2018) Trade and Globalization. Режим доступа: https:// ourworldindata.org/trade-and-globalization (дата обращения: 14.06.2019).

Park S.-C. (2017) Can Trade Help Overcome Economic Crisis? Implications for Northeast Asia Creating a Regional FTA between Korea, China, and Japan and Mega FTAs Such as RCEP and TPP // International Organisations Research Journal. Vol. 12. No. 2. P. 104-28.

Park S.-C., Pasierbiak P. (2018) Japan's Role in East Asian Economic Regionalism // Institutions and Economies. Vol. 10. No. 2. P. 121-45.

Partington R. (2018) IMF Warns Trump Trade War Could Cost Global Economy \$430bn // The Guardian. 16 July. Режим доступа: https://www.theguardian.com/business/2018/jul/16/imf-trump-trade-warglobaleconomy-us-tariff-weo (дата обращения: 23.09.2018).

de Prado C. (2014) Prospects for the EU - Japan Strategic Partnership: A Global Multi-level and SWOT Analysis. European University Institute. Режим доступа: https://www.eu-japan.eu/sites/default/files/publications/docs/eujpstrategicpartnership.pdf (дата обращения: 18.04.2019).

Rosen H.F. (2008) Strengthening Trade Adjustment Assistance. Policy Brief 08-2, Peterson Institute for International Economics. Режим доступа: https://piie.com/sites/default/files/publications/pb/pb08-2.pdf (дата обращения: 01.06.2018).

Samuelson P. (2004) Where Ricardo and Mill Rebut and Confirm Arguments of Mainstream Economists Supporting Globalization // Journal of Economic Perspectives. Vol. 18. No. 3. P. 135-146.

Sugawara J. (2017) Significance of the Japan-EU EPA: The Agreement in Principle: Restart of Japan's Trade Strategy // Mizuho Economic Outlook and Analysis. 12 July. Режим доступа: https://www.mizuho-ri.co.jp/ publication/research/pdf/eo/MEA170814.pdf (дата обращения: 11.05.2018).

Tatsushi O. (2002) An Approach towards Japan's FTA Policy. Working Paper Series 01-02 No 4, IDE APEC Study Center. Режим доступа: https://www.ide.go.jp/library/English/Publish/Download/Apec/ pdf/2001_16.pdf (дата обращения: 01.06.2019).

Yamamoto Y., Kikuchi T. (1998) Japan's Approach to APEC and Regime Creation in the Asia Pacific. Asia Pacific Crossroads: Regime Creation and the Future of APEC / V.K. Aggarwal, C.E. Morrison (eds). N.Y.: St Martin's Press.

World Bank (2017) World Development Indicators. 21 November. Washington, DC: World Bank.

World Trade Organization (WTO) (2018) World Trade Statistical Review 2018, Geneva: WTO. 